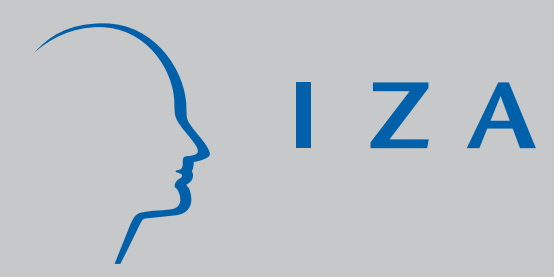

IZA DP No. 2900

The Evolution of Inflation and Unemployment: Explaining the Roaring Nineties

Marika Karanassou

Hector Sala

Dennis J. Snower

J uly 2007 


\title{
The Evolution of Inflation and Unemployment: Explaining the Roaring Nineties
}

\author{
Marika Karanassou \\ Queen Mary, University of London \\ and IZA \\ Hector Sala \\ Universitat Autònoma de Barcelona \\ and IZA \\ Dennis J. Snower \\ Kiel Institute for the World Economy, \\ University of Kiel, CEPR and IZA
}

Discussion Paper No. 2900

July 2007

IZA

P.O. Box 7240

53072 Bonn

Germany

Phone: +49-228-3894-0

Fax: +49-228-3894-180

E-mail: iza@iza.org

\begin{abstract}
Any opinions expressed here are those of the author(s) and not those of the institute. Research disseminated by IZA may include views on policy, but the institute itself takes no institutional policy positions.

The Institute for the Study of Labor (IZA) in Bonn is a local and virtual international research center and a place of communication between science, politics and business. IZA is an independent nonprofit company supported by Deutsche Post World Net. The center is associated with the University of Bonn and offers a stimulating research environment through its research networks, research support, and visitors and doctoral programs. IZA engages in (i) original and internationally competitive research in all fields of labor economics, (ii) development of policy concepts, and (iii) dissemination of research results and concepts to the interested public.
\end{abstract}

IZA Discussion Papers often represent preliminary work and are circulated to encourage discussion. Citation of such a paper should account for its provisional character. A revised version may be available directly from the author. 
IZA Discussion Paper No. 2900

July 2007

\section{ABSTRACT \\ The Evolution of Inflation and Unemployment: Explaining the Roaring Nineties}

This paper analyses the relation between US inflation and unemployment from the perspective of "frictional growth," a phenomenon arising from the interplay between growth and frictions. In particular, we examine the interaction between money growth (on the one hand) and various real and nominal frictions (on the other). In this context we show that monetary policy has not only persistent, but permanent real effects, giving rise to a long-run inflation-unemployment tradeoff. We evaluate this tradeoff empirically and assess the impact of productivity, money growth, budget deficit, and trade deficit on the US unemployment and inflation trajectories during the nineties.

JEL Classification: E24, E31, E51, E62

Keywords: inflation dynamics, unemployment dynamics, Phillips curve, roaring nineties

Corresponding author:

Hector Sala

Departament d'Economia Aplicada

Universitat Autònoma de Barcelona

08193 Bellaterra

Spain

E-mail: hector.sala@uab.es

\footnotetext{
* Hector Sala is grateful to the Spanish Ministry of Education and Science for financial support through grant SEJ2006-14849/ECON.
} 


\section{Introduction}

The aim of this paper is to shed light on the inflation-unemployment relationship and, in this context, explore the driving forces underlying the "roaring nineties" in the US: the dream combination of low inflation, low unemployment and strong growth. ${ }^{1}$ We will examine how these conditions were generated by a combination of money growth, productivity growth, the budget deficit, and the trade deficit. In this context, we will investigate the long-lasting effects of monetary policy on real macroeconomic activity.

Our analysis centers on "frictional growth," a phenomenon arising from the interplay between growth and frictions. In particular, we examine the interaction between money growth (on the one hand) and various nominal frictions (on the other). In this context we show that monetary policy has not only persistent, but permanent real effects, giving rise to a long-run inflation-unemployment tradeoff.

The orthodox view that there is no long-run relationship between inflation and unemployment has led to a compartmentalisation in macro-labour economics: one branch of the literature examines the real variables driving unemployment, and another branch explores inflation dynamics. ${ }^{2}$ In recent years, this orthodoxy has been weakened somewhat through the microfoundations of the New Phillips curve, which can be expressed as $\pi_{t}=\beta E_{t} \pi_{t+1}-a\left(u_{t}-u^{n}\right)+\varepsilon_{t}$, where $\pi_{t}$ is the inflation rate, $u_{t}$ is the unemployment rate, $u^{n}$ is the natural rate of unemployment, and $\beta$ is the discount factor. But since the discount factor is close to unity, the long-run Phillips curve is still presumed to be approximately vertical. ${ }^{3}$

However, the theoretical literature (dating back to Sidrauski, 1967) indicates that the superneutrality of money (necessary for the existence of a vertical long-run Phillips curve) rests on special, strong assumptions, such as the separability of consumption and leisure in utility and the role of money in the economy (see, for example, Orphanides and Solow, 1990, for a survey).

The more recent theoretical literature on the New Phillips Curve suggests the same conclusion. As is well-known, the long-run relation between inflation and unemployment implied by the NPC $(d \pi / d u=-a /(1-\beta)$ for the Phillips equation above) is due to the interaction between money growth and nominal frictions in the presence of discounting. Under staggered price setting, the discounting effect causes current prices to depend more heavily on the past price level than on the future price level. The faster the money supply grows, the greater is the spread between future and past price levels, and since the past price

\footnotetext{
${ }^{1}$ For some background to the performance of the US economy, see for example Blinder and Yellen (2002), and Stiglitz (2003).

${ }^{2}$ As Mishkin (2006) puts it, the absence of a long-run inflation-unemployment tradeoff is one of 'six ideas that are now accepted by monetary authorities and governments in almost all countries of the world'.

${ }^{3}$ Karanassou and Snower (2007) argue that this presumption can be misleading. For plausible parameter values, they show that a positive discount rate generates substantial inflation undershooting and the new Phillips curve is downward-sloping in the long-run.
} 
level has a stronger influence than the future price level on current prices, the current price level falls relative to the money supply. This interplay between money growth and nominal frictions has been called "frictional growth" (see Karanassou, Sala and Snower, 2005).

Whereas the standard NPC contains only one growing variable (the money supply, responsible for inflation) and one nominal friction (e.g. staggered prices), in practice there are many growing variables in modern economies (e.g. the capital stock, output, population) and many nominal frictions. The analysis of the interaction of these various variables is still in its infancy, but we know for example that staggered wage setting and staggered price setting are complementary in generating monetary persistence (see, for example, Merkl and Snower, 2006). In this context, once again, the slope of the long-run Phillips curve becomes an empirical matter.

The main purpose of this paper is to explore this empirical issue by estimating a system of macroeconomic equations with several growing variables and several nominal frictions. Before doing so, we outline a simple theoretical model which provides some useful intuitive insights.

The rest of the paper is structured as follows. Section 2 analyses a dynamic model consisting of wage/price and labour demand/supply equations, and shows how it generates a nonvertical Phillips curve in the long-run. Section 3 estimates such an interactive dynamics model (i.e. a dynamic multi-equation model with spillover effects) for the US that also includes equations for productivity and financial wealth. This empirical model is used in Sections 4 and 5 to derive the Phillips curve, and reappraise the performance of the US economy during the roaring nineties, respectively. Section 6 outlines the popular alternative methodologies of GMM and SVARs, and applies these econometric techniques to evaluate the inflation-unemployment tradeoff. Finally, Section 7 concludes.

\section{Frictional Growth and the Phillips Curve}

We illustrate the effects of frictional growth on the Phillips curve through a simple, stylised macro model containing several growing variables and nominal frictions.

While a full microfoundations lies beyond the scope of this paper our model captures the essential relationships responsible for long-run effects of monetary policy. A fully microfounded model, with both wage and price staggering, and yielding similar outcomes than this stylised model, is developed in Merkl and Snower (2006).

It is also important to remark that wage and price equations that have both leads and lags can be expressed solely in terms of current and lagged variables. For this, expectations of future variables need to be expressed in terms of current and past variables. ${ }^{4}$ More

\footnotetext{
${ }^{4}$ Under price staggering, for example, current prices depend on past and expected future prices. After specifying the agents' information sets and solving the model, the expected future prices may be expressed in terms of present and past variables. Karanassou, Sala and Snower (2005, 2007) show that the rational-
} 
generally, the equations below may be interpreted as reduced forms, in which the expected lead variables are expressed in terms of the current and past variables in agents' current information sets.

Our model is thus to be understood along these lines, but is deliberately kept simple to provide some useful intuitive insights related to frictional growth. It comprises the following nominal wage $\left(W_{t}\right)$, price $\left(P_{t}\right)$, labour demand $\left(n_{t}\right)$, and labour supply $\left(l_{t}\right)$ equations:

$$
\begin{aligned}
W_{t} & =\alpha_{W} W_{t-1}+\left(1-\alpha_{W}\right) M_{t}+\alpha_{b} b_{t}-\alpha_{u} u_{t}, \\
P_{t} & =\alpha_{P} P_{t-1}+\left(1-\alpha_{P}\right) M_{t}, \\
n_{t} & =\beta_{k} k_{t}-\beta_{w} w_{t}+\beta_{m}\left(M_{t}-P_{t}\right), \\
l_{t} & =\gamma_{z} z_{t}+\gamma_{w} w_{t},
\end{aligned}
$$

where the autoregressive parameters $\left(0<\alpha_{W}, \alpha_{P}<1\right)$ capture wage and price staggering effects, and $\alpha_{b}, \alpha_{u}$, the $\beta$ s and the $\gamma_{s}$ are positive constants. $w_{t} \equiv W_{t}-P_{t}$ is real wage, and $M_{t}, b_{t}, k_{t}$, and $z_{t}$ denote the money supply, real benefits, real capital stock, and working-age population, respectively (constant and error terms are ignored for expositional ease). All variables are in logs and the unemployment rate $\left(u_{t}\right)$ is approximated by the difference of (log) labour force and (log) employment:

$$
u_{t}=l_{t}-n_{t} .
$$

Observe that the nominal equations (1)-(2) satisfy the no money illusion (or money neutrality) restriction in the long-run, since the steady-state elasticities of wages and prices with respect to money are unity. It is also worth pointing out that $\alpha_{u}, \beta_{w}, \beta_{m}$ and $\gamma_{w}$ generate spillover effects, since changes in an exogenous variable, say benefits, can also affect labour demand and supply equations (via $\beta_{w}$ and $\gamma_{w}$ ). Note that it is the existence of spillovers in a multi-equation system that defines an interactive model. In the presence of spillover effects, the short-run elasticities of the dependent variables with respect to the exogenous ones can no longer be adequately captured by $\alpha_{b}, \beta_{k}$ and $\gamma_{z}$. We refer to the latter as the short-run "local" elasticities, to distinguish them from the "global" elasticities that result from the interactions in the system.

In the context of equations (1)-(4), let us derive the unemployment rate as a function of its own lags and the exogenous variables. First, subtracting (2) from (1) and further algebraic manipulation leads to the following real wage equation:

$$
\left(1-\alpha_{W} B\right)\left(1-\alpha_{P} B\right) w_{t}=\alpha_{b}\left(1-\alpha_{P} B\right) b_{t}+\left(\alpha_{P}-\alpha_{W}\right) \mu_{t}-\alpha_{u}\left(1-\alpha_{P} B\right) u_{t},
$$

expectations solution of wage-price staggering models translates the expected future values of the variables into the current and past values. 
where $B$ is the backshift operator, and $\mu_{t} \equiv M_{t}-M_{t-1}$ is the money growth rate. Note that (i) money growth affects real wages in all horizons when $\alpha_{P} \neq \alpha_{W}$, and (ii) the real wage is procyclical when price inertia exceeds wage inertia $\left(\alpha_{P}>\alpha_{W}\right)$.

Second, algebraic manipulation of the price (2) gives the following dynamics for real money balances:

$$
\left(1-\alpha_{P} B\right)\left(M_{t}-P_{t}\right)=\alpha_{P} \mu_{t}
$$

Third, substitution of real wage (6) and real balances (7) into the demand (3) and supply (4) equations, and further algebraic manipulation, gives

$$
\begin{aligned}
\left(1-\alpha_{W} B\right)\left(1-\alpha_{P} B\right) n_{t}= & \beta_{k}\left(1-\alpha_{W} B\right)\left(1-\alpha_{P} B\right) k_{t} \\
& +\beta_{m} \alpha_{P}\left(1-\alpha_{W} B\right) \mu_{t}-\beta_{w}\left(\alpha_{P}-\alpha_{W}\right) \mu_{t} \\
& -\beta_{w} \alpha_{b}\left(1-\alpha_{P} B\right) b_{t}+\beta_{w} \alpha_{u}\left(1-\alpha_{P} B\right) u_{t},
\end{aligned}
$$

and

$$
\begin{aligned}
\left(1-\alpha_{W} B\right)\left(1-\alpha_{P} B\right) l_{t}= & \gamma_{z}\left(1-\alpha_{W} B\right)\left(1-\alpha_{P} B\right) z_{t}+\gamma_{w}\left(\alpha_{P}-\alpha_{W}\right) \mu_{t} \\
& +\gamma_{w} \alpha_{b}\left(1-\alpha_{P} B\right) b_{t}-\gamma_{w} \alpha_{u}\left(1-\alpha_{P} B\right) u_{t}
\end{aligned}
$$

respectively.

Finally, we obtain the reduced form dynamics of the unemployment rate by subtracting (8) from $(9):^{5}$

$$
\begin{gathered}
\left(1-\alpha_{P} B\right)\left[\left(1-\alpha_{W} B\right)+\gamma_{u}\left(\beta_{w}+\gamma_{w}\right)\right] u_{t}=\left[\left(\alpha_{P}-\alpha_{W}\right)\left(\beta_{w}+\gamma_{w}\right)-\beta_{m} \alpha_{P}\left(1-\alpha_{W} B\right)\right] \mu_{t} \\
+\left(1-\alpha_{P} B\right)\left[\gamma_{z}\left(1-\alpha_{W} B\right) z_{t}-\beta_{k}\left(1-\alpha_{W} B\right) k_{t}+\alpha_{b}\left(\beta_{w}+\gamma_{w}\right) b_{t}\right] .
\end{gathered}
$$

This equation is also referred to as the univariate representation of unemployment, since no other endogenous variables appear on its right-hand side. The term "reduced form" relates to the fact that the parameters of the equation, instead of being directly estimated, are some nonlinear function of the parameters of the underlying macro model (1)-(4).

Recall that $\alpha_{W}$ and $\alpha_{P}$ are associated with price and wage staggering, respectively, $\alpha_{u}$ reflects the downward pressure of unemployment on wages, $\beta_{w}$ depicts the wage elasticity of labour demand, $\beta_{m}$ is the elasticity of labour demand with respect to real money balances, $\gamma_{w}$ is the wage elasticity of labour supply, and $\alpha_{b}, \beta_{k}, \gamma_{z}$ measure the "local" elasticities of the exogenous variables.

The univariate representation of the unemployment rate (10) highlights the following relations embedded in our macro model.

\footnotetext{
${ }^{5}$ Note that (10) is dynamically stable since (i) products of polynomials in $B$ which satisfy the stability conditions are stable, and (ii) linear combinations of dynamically stable polynomials in $B$ are also stable.
} 
First, if $\alpha_{W}>\alpha_{P}$, an increase in money growth $\left(\mu_{t}\right)$ reduces both unemployment (by eq. (10)) and real wages (by eq. (6)). Put it differently, the real wage is countercyclical when prices adjust faster than nominal wages. On the other hand, if $\alpha_{W}<\alpha_{P}$, an expansionary monetary policy reduces unemployment ${ }^{6}$ and increases real wages. That is, the real wage is procyclical when prices adjust slower than wages.

Second, the transmission mechanisms of monetary policy are: (i) the direct channel of real money balances in the labour demand equation $\left(\beta_{m} \neq 0\right)$, and (ii) the indirect channels of real wage in labour demand and supply $\left(\beta_{w} \neq 0\right.$ and $\gamma_{w} \neq 0$, respectively). ${ }^{7}$

Third, if $\alpha_{u}=0$, changes in capital stock $\left(k_{t}\right)$ and working-age population $\left(z_{t}\right)$ do not spillover to the system. This is because labour demand and labour supply shocks are transmitted to the rest of the system via wages. If changes in the capital stock (working-age population) do not influence wages $\left(\alpha_{u}=0\right)$, they cannot spillover from labour demand (supply) to the other equations. Therefore, the effects of these variables on unemployment can be adequately captured by the individual labour demand (3) and supply (4) equations, respectively, and there is no value added from the reduced form unemployment rate eq. (10).

Finally, if $\beta_{w}=\gamma_{w}=0$, changes in benefits $\left(b_{t}\right)$ do not spillover to either labour demand or supply, and, thus, do not affect unemployment.

We can reparameterise the univariate representation of the unemployment rate (10) as

$$
\begin{aligned}
u_{t} & =\phi_{1} u_{t-1}-\phi_{2} u_{t-2}-\theta_{\mu} \mu_{t}+\beta_{m} \phi_{2} \mu_{t-1}+\theta_{z} z_{t}-\theta_{z}\left(\alpha_{W}+\alpha_{P}\right) z_{t-1}+\theta_{z} \alpha_{W} \alpha_{P} z_{t-2} \\
& -\theta_{k} k_{t}+\theta_{k}\left(\alpha_{W}+\alpha_{P}\right) k_{t-1}-\theta_{k} \alpha_{W} \alpha_{P} k_{t-2}+\theta_{b} b_{t}-\theta_{b} \alpha_{P} b_{t-1} .
\end{aligned}
$$

where $\phi_{1}=\frac{\alpha_{W}+\alpha_{P}+\alpha_{P} \gamma_{u}\left(\beta_{w}+\gamma_{w}\right)}{1+\alpha_{u}\left(\beta_{w}+\gamma_{w}\right)}, \phi_{2}=\frac{\alpha_{W} \alpha_{P}}{1+\alpha_{u}\left(\beta_{w}+\gamma_{w}\right)}, \theta_{\mu}=\frac{\left(\alpha_{W}-\alpha_{P}\right)\left(\beta_{w}+\gamma_{w}\right)+\beta_{m} \alpha_{P}}{1+\alpha_{u}\left(\beta_{w}+\gamma_{w}\right)}, \theta_{z}=\frac{\gamma_{z}}{1+\alpha_{u}\left(\beta_{w}+\gamma_{w}\right)}$, $\theta_{k}=\frac{\beta_{k}}{1+\alpha_{u}\left(\beta_{w}+\gamma_{w}\right)}$, and $\theta_{b}=\frac{\alpha_{b}\left(\beta_{w}+\gamma_{w}\right)}{1+\alpha_{u}\left(\beta_{w}+\gamma_{w}\right)}$.

The above equation illuminates the key feature of the CRT: the unemployment rate is the outcome of the interactions of the wage and price staggering adjustment processes, $\alpha_{W}$ and $\alpha_{P}$, and the feedback mechanisms of the macro model, i.e. $\alpha_{u}, \beta_{w}, \beta_{m}$ and $\gamma_{w}$. Note that the $\theta$ s are the short-run "global" elasticities of unemployment with respect to the exogenous variables. The univariate representation of unemployment (11) can be understood as an autoregressive moving average (ARMA) process with the lags of the exogenous variables being the moving-average terms.

\footnotetext{
${ }^{6}$ This holds when

$$
\beta_{m} \alpha_{P}\left(1-\alpha_{W}\right)>\left(\alpha_{P}-\alpha_{W}\right)\left(\beta_{w}+\gamma_{w}\right) .
$$

${ }^{7}$ Indirect in the sense that monetary policy first affects nominal wages $\left(\alpha_{W} \neq 0\right)$ and prices $\left(\alpha_{P} \neq 0\right)$, and then transmits to unemployment via real wages in the labour demand and supply equations.
} 


\subsection{The Long-run}

Another key feature of the univariate representation (11) is that trended variables, like capital stock and working-age population, influence the time path of the nontrended unemployment rate. This controversial result can be explained as follows. Recall from eq. (3) and (4) that the trended series of employment and labour force are determined by the trended variables of capital stock and working age population, and the real wage. According to (8)-(9), labour demand and supply remain balanced after substituting in the real wage equation (6) since they are dynamically stable $\left(\left|\alpha_{W}, \alpha_{P}\right|<1\right){ }^{8}$

Therefore, the reduced form unemployment rate equation (10) is itself dynamically stable, since (by (5)) it is the difference of the dynamically stable labour supply and demand equations. Karanassou and Snower (2004) show that equilibrating mechanisms in the labour market and other markets jointly act to ensure that the unemployment rate is trendless in the long-run (see, also, Karanassou, Sala, and Salvador, 2007). These mechanisms can be expressed in the form of restrictions on the relationships between the long-run growth rates of capital stock and the other growing exogenous variables.

First differencing (10), setting $B=1$, recognising that money growth $\left(\mu_{t}\right)$ stabilises in the long-run, and assuming that the exogenous variables are characterised by nonzero longrun growth rates, gives the following equation for the long-run change in unemployment:

$$
\left(1-\alpha_{P}\right)\left[\left(1-\alpha_{W}\right)+\alpha_{u}\left(\beta_{w}+\gamma_{w}\right)\right] \Delta u^{L R}=\left(1-\alpha_{P}\right)\left[\begin{array}{c}
\gamma_{z}\left(1-\alpha_{W}\right) \Delta z^{L R} \\
-\beta_{k}\left(1-\alpha_{W}\right) \Delta k^{L R} \\
+\alpha_{b}\left(\beta_{w}+\gamma_{w}\right) \Delta b^{L R}
\end{array}\right]
$$

where $\Delta$ is the difference operator and $(\cdot)^{L R}$ denotes the long-run value of the variable. The above equation shows that the unemployment rate stabilises in the long-run, i.e. $\Delta u^{L R}=0$, when the long-run growth rates of the exogenous variables satisfy the following restriction:

$$
\beta_{k} \Delta k^{L R}=\gamma_{z} \Delta z^{L R}+\frac{\alpha_{b}\left(\beta_{w}+\gamma_{w}\right)}{\left(1-\alpha_{W}\right)} \Delta b^{L R}
$$

where $\Delta k, \Delta z, \Delta b$ are the growth rates of capital stock, working-age population, and benefits, respectively.

We should point out that the specification of real wage (6) is a manifestation of frictional growth. Thus, one implication of frictional growth is that the interplay of wage/price staggering and the growing money supply generates real effects of the monetary policy in both the short- and long-run, despite the no money illusion restriction imposed on the wage and price setting eq. (1)-(2). ${ }^{9}$ That is, the classical dichotomy evaporates in the

\footnotetext{
${ }^{8}$ Note that (8) and (9) are dynamically stable since the products of polynomials in $B$ which satisfy the stability conditions are also stable.

${ }^{9}$ For a discussion of the concepts of the short-run, steady-state, and long-run, see Karanassou, Sala, and
} 
presence of frictional growth.

In particular, the long-run solution of the price eq. (2) is

$$
\begin{aligned}
& \underset{\text { long-run }}{P_{t R}^{L R}}=M_{t}^{L R}-\frac{\alpha_{P}}{1-\alpha_{P}} \Delta P^{L R} \\
& =\underbrace{M_{t}^{L R}}_{\text {frictionless steady-state }}-\underbrace{\frac{\alpha_{P}}{1-\alpha_{P}} \mu^{L R}}_{\text {frictional growth }},
\end{aligned}
$$

where the subscript $t$ signifies that the variable does not stabilise in the long-run. Note that, even in the absence of money illusion, the growing price level does not catch up with the growing money supply in the long-run due to frictional growth. However, due to no money illusion (money neutrality) inflation equals money growth in the long-run:

$$
\pi^{L R}=\mu^{L R}
$$

Furthermore, the long-run solution of the wage eq. (1) is given by

$$
\begin{aligned}
\begin{aligned}
W_{t}^{L R} \\
\text { long-run }
\end{aligned} & =M_{t}^{L R}+\frac{\alpha_{b}}{1-\alpha_{W}} b_{t}^{L R}-\frac{\alpha_{u}}{1-\alpha_{W}} u^{L R}-\frac{\alpha_{W}}{1-\alpha_{W}} \Delta W^{L R} \\
& =\underbrace{M_{t}^{L R}+\frac{\alpha_{b}}{1-\alpha_{W}} b_{t}^{L R}-\frac{\alpha_{u}}{1-\alpha_{W}} u^{L R}}_{\text {frictionless steady-state }}-\underbrace{\frac{\alpha_{W} \alpha_{b}}{\left(1-\alpha_{W}\right)^{2}} \Delta b^{L R}-\frac{\alpha_{W}}{1-\alpha_{W}} \mu^{L R}}_{\text {frictional growth }} .
\end{aligned}
$$

By subtracting (13) from (15) we get the following long-run real wage equation:

$$
\begin{gathered}
w_{t}^{L R} \\
\text { long-run }
\end{gathered}=\underbrace{\left(\frac{\alpha_{b}}{1-\alpha_{W}} b_{t}^{L R}-\frac{\alpha_{u}}{1-\alpha_{W}} u^{L R}\right)}_{\text {frictionless steady state }}+\underbrace{\frac{\left(\alpha_{P}-\alpha_{W}\right) \mu^{L R}}{\left(1-\alpha_{W}\right)\left(1-\alpha_{P}\right)}-\frac{\alpha_{W} \alpha_{b}}{1-\alpha_{W}} \Delta b^{L R}}_{\text {frictional growth }} .
$$

It is clear from the above equation that money growth $(\mu)$ affects real wages in the long-run. Consequently, by (14) and for $\alpha_{W} \neq \alpha_{P}$, the above equation implies that the Phillips curve is not vertical in the long-run since unemployment depends on real wages.

A second important implication of frictional growth is that under quite plausible conditions the natural rate is not an attractor of the unemployment trajectory. We derive this result below.

The long-run solutions of labour supply (4) and demand (3) are

$$
\begin{aligned}
l_{t}^{L R} & =\gamma_{z} z_{t}^{L R}+\gamma_{w} w_{t}^{L R} \text { and } \\
n_{t}^{L R} & =\beta_{k} k_{t}^{L R}-\beta_{w} w_{t}^{L R}+\beta_{m}(M-P)^{L R},
\end{aligned}
$$

respectively. Subtraction of (18) from (17), and further algebraic manipulation, leads to the Snower (2006). 
following long-run unemployment rate equation:

$$
\begin{aligned}
u^{L R}= & \underbrace{\xi\left[\gamma_{z} z_{t}^{L R}-\beta_{k} k_{t}^{L R}+\frac{\alpha_{b}\left(\beta_{w}+\gamma_{w}\right)}{\left(1-\alpha_{W}\right)} b_{t}^{L R}\right]}_{\text {frictionless steady-state (NRU) }} \\
& +\underbrace{\xi\left[\frac{\left(\alpha_{P}-\alpha_{W}\right)\left(\beta_{w}+\gamma_{w}\right)-\left(1-\alpha_{W}\right) \beta_{m} \alpha_{P}}{\left(1-\alpha_{W}\right)\left(1-\alpha_{P}\right)} \pi^{L R}-\frac{\alpha_{W} \alpha_{b}\left(\beta_{w}+\gamma_{w}\right)}{\left(1-\alpha_{W}\right)} \Delta b^{L R}\right]}_{\text {frictional growth }},
\end{aligned}
$$

where $\xi=\frac{1-\alpha_{W}}{1-\alpha_{W}+\alpha_{u}\left(\beta_{w}+\gamma_{w}\right)}$. Note that the frictional growth term is constant, while the steady-state term stabilises in the long-run under (12). Thus, condition (12) ensures that the unemployment rate is constant in the long-run.

In single-equation unemployment rate models the natural rate of unemployment (NRU) is obtained by the steady-state solution of the equation, and it easy to show that actual unemployment gravitates towards its natural rate. In sharp contrast, eq. (19) predicts that in the context of interactive dynamic labour-macro models with growing exogenous variables, unemployment may deviate substantially from what is commonly perceived as its natural rate, even in the long-run. ${ }^{10}$ The long-run value $\left(u^{L R}\right)$ towards which the unemployment rate converges reduces to the NRU only when frictional growth is zero, i.e. when the exogenous variables have zero growth rates or there are no lags in the system.

\section{$2.2 \quad$ Persistence and Elasticities}

The effects of shocks to dynamic models persist for much longer than the duration of the shocks and eventually die out long after the shocks are over. The impulse response function of unemployment describes its responses through time to a one-off shock (impulse), and persistence measures the after effects of the shock.

For a temporary shock occurring at period $t$, we define unemployment persistence $(\sigma)$ as the sum of its responses for all periods $t+j$ in the aftermath of the shock $(j \geq 1):^{11}$

$$
\sigma \equiv \sum_{j=1}^{\infty} R_{t+j}
$$

where the series $R_{t+j}, j \geq 0$ is the impulse response function (IRF) of unemployment. ${ }^{12}$ We can distinguish the following cases: (i) $\sigma=0$, i.e. the shock is absorbed instantly, when the unemployment rate model is static, (ii) $\sigma \neq 0$, i.e. the effects of the shock gradually

\footnotetext{
${ }^{10}$ See also Karanassou and Snower (1997), and Karanassou, Sala, and Salvador (2006).

${ }^{11}$ Other measures of persistence are the half life of the shock, the sum of the autoregressive parameters, and the largest autoregressive root. The virtues and faults of these measures are pointed out in a recent application by Pivetta and Reis (2007).

${ }^{12}$ In other words, $R_{t+j}, j \geq 0$, denotes the coefficients of the infinite moving average representation of unemployment with respect to the shock.
} 
dissipate through time, when the model is dynamically stable, and (iii) $\sigma=\infty$, i.e. the temporary shock has a permanent effect, when the model displays hysteresis.

Note that when we view the shock at period $t$ as a change in one of the explanatory variables over that period, the immediate response $\left(R_{t}\right)$ is simply the short-run "global" elasticity (slope) of unemployment with respect to that variable, while the sum of the current impact $\left(R_{t}\right)$ and persistence $(\sigma)$ gives the long-run "global" elasticity (slope) of unemployment with respect to the variable. In other words, the long-run elasticity $\left(e_{L R}\right)$ can be decomposed into the short-run elasticity $\left(e_{S R}\right)$ and our measure of persistence $(20)$ :

$$
e_{S R}+\sigma=e_{L R}
$$

The above relation essentially uses the IRF of the shock to obtain the short- and longrun elasticities of the model, and thus offers an additional diagnostic tool for the estimated macro-labour system. In a large interactive model, mere inspection of the individual equations only gives the "local" (direct) short-run elasticities of the exogenous variables. The "global" short-run elasticity is influenced by the feedback mechanisms of the system and can be effectively measured by the contemporaneous response. Furthermore, the sum of the short-run elasticity and the "future" responses (i.e. persistence) gives the "global" long-run elasticity. The economic plausibility of the signs and magnitudes of the elasticities of the various exogenous variables serves to diagnose the model in hand. We believe that a crucial factor that led to the demise of the large macro-econometric models, very popular in the past, was the lack of such a diagnosis.

\section{An Empirical Model of the US Economy}

Along the lines of the analytical model in the previous section, we capture the phenomenon of frictional growth by estimating an interactive dynamics model for the US economy comprising wage/price setting and labour market equations. This model is an expanded version of the three-equation system in Karanassou, Sala, and Snower (2005) as it endogenises productivity and financial wealth, and derives the unemployment rate from labour supply and demand equations. Thus, our empirical model consists of a six-equation structural system (plus the definition of the unemployment rate). Our model can jointly explain the evolution of unemployment and inflation. At the same time, the interplay of money growth and nominal frictions gives rise to a downward-sloping Phillips curve (PC) in the long-run.

We should emphasize that, although the wage and price equations depend only on lags (and not leads), they derive from staggering equations that contain backward- and forwardlooking components. Karanassou, Sala, and Snower $(2005,2007)$ show that the rational expectations solution of wage/price staggering models translates the expected future values of the variables into their current and past values. 


\subsection{Data and Estimation Methodology}

We use annual data, over the 1960-2005 period, obtained from Bloomberg (S\&P's 500 index), Datastream (oil prices) and the OECD (rest of the variables). Table 1 provides the definitions of the variables used in the estimated model.

\begin{tabular}{|ll|ll|}
\hline \multicolumn{2}{|l|}{ Table 1: Definitions of variables. } \\
\hline$M_{t}$ & money supply (M3) & $\pi$ & price inflation $\left(P_{t}-P_{t-1}\right)$ \\
$P_{t}$ & price level (GDP deflator) & $\mu$ & money growth $\left(\Delta M_{t}\right)$ \\
$W_{t}$ & nominal compensation & $f w_{t}$ & financial wealth (real S\&P's 500) \\
$w_{t}$ & real wage $\left(W_{t}-P_{t}\right)$ & $k_{t}$ & real capital stock \\
$p r_{t}$ & real labour productivity & oil & real oil prices \\
$n_{t}$ & employment & $i m p_{t}$ & real import prices (goods \& services) \\
$l_{t}$ & labour supply & $z_{t}$ & working-age population \\
$u_{t}$ & unemployment rate $\left(l_{t}-n_{t}\right)$ & $c o n s_{t}$ & private consumption, \% of GDP \\
$\operatorname{tax} x_{t}^{s s}$ & social security contributions, \% of GDP & $g o v_{t}$ & public expenditures, \% of GDP \\
$t_{t}^{i}$ & indirect taxes, \% of GDP & $f d_{t}$ & foreign demand: exports-imports, \% of GDP \\
$\operatorname{tax}_{t}^{d}$ & direct taxes paid by & $t$ & linear time trend \\
\multicolumn{2}{|l|}{ households, \% of GDP } & $c$ & constant \\
\hline All variables are in logs except for the unemployment rate $u_{t}$ and the ratios. \\
Source: Bloomberg, Datastream and OECD. \\
\hline
\end{tabular}

Our econometric methodology is based on the autoregressive distributed lag (ARDL) approach developed by Pesaran (1997), Pesaran and Shin (1999) and Pesaran, Shin and Smith (2001). These authors argue that the ARDL is an alternative to the cointegration error-correction methodology with the advantage of avoiding the pretesting problem implicit in the standard cointegration techniques (i.e. the Johansen maximum likelihood, and the Phillips-Hansen semi-parametric fully-modified OLS procedures). In fact, they show that the ARDL yields consistent short- and long-run estimates, and can be reliably used in small samples for hypothesis testing irrespective of whether the regressors are $\mathrm{I}(1)$ or $\mathrm{I}(0)$.

Our empirical CRT macro-labour model is given by the following system of nominal and real equations: ${ }^{13}$

$$
\mathbf{A}_{0} \mathbf{y}_{t}=\sum_{i=1}^{2} \mathbf{A}_{i} \mathbf{y}_{t-i}+\sum_{i=0}^{2} \mathbf{D}_{i} \mathbf{x}_{t-i}+\varepsilon_{t}
$$

where $\mathbf{y}_{t}$ is a $(6 \times 1)$ vector of endogenous variables (prices, wages, financial wealth, employment, labour force and productivity), $\mathbf{x}_{t}$ is a $(10 \times 1)$ vector of exogenous variables, the As and Ds are $(6 \times 6)$ and $(10 \times 10)$ coefficient matrices, respectively, and $\varepsilon_{t}$ is a $(6 \times 1)$ vector of strict white noise error terms. (Constants and trends are omitted for ease of exposition.)

\footnotetext{
${ }^{13}$ The dynamic system (22) is stable when, for given values of the exogenous variables, all the roots of the determinantal equation

$$
\left|\mathbf{A}_{0}-\mathbf{A}_{1} B-\mathbf{A}_{2} B^{2}\right|=0
$$
}

lie outside the unit circle. Note that the estimated equations given below satisfy this condition. 
The ARDL methodology is applied to each equation of the CRT model (22), and the selected equations pass the standard diagnostic tests for structural stability, linearity, serial correlation, heteroskedasticity (and autoregressive conditional heteroskedasticity), and normality. (The tests are available upon request.) In the next section we discuss the estimation results and provide an overall evaluation of our empirical macro-labour model. ${ }^{14}$

\subsection{Estimated Equations}

Tables 2 and 3 display the results on the estimated equations. The price equation exhibits a persistence coefficient of 0.65, as in Karanassou, Sala and Snower (2005), with supply-side influences captured via nominal wages, with a positive sign, and productivity, with a negative sign. The restriction of no money illusion in the long-run is imposed so that the price equation is homogeneous of degree zero in the nominal variables. ${ }^{15}$ With respect to productivity, the long-run elasticity of -0.71 indicates that almost three quarters of productivity gains are translated into price reductions. This price setting curve can be interpreted as the outcome of price-staggering, where the demand conditions are captured by investment (proxied by the growth in capital stock, $\Delta k$ ), consumption, government expenditures, and foreign demand, all with the expected upward pressure on prices. Since the latter three variables are expressed as a percentage of GDP, their estimated coefficients show how prices change in response to increases in these variables relative to output. Note that prices are more sensitive to fluctuations in the trade surplus/deficit than to changes in either consumption or government expenditures.

The nominal wage equation is quite standard and satisfies the restriction of no money illusion. ${ }^{16}$ The persistence coefficient of 0.51 implies that wages adjust faster than prices (similarly to Karanassou, Sala and Snower, 2005). The long-run elasticity of wages with respect to productivity is 0.65 , indicating that about two thirds of productivity gains are translated into wage increases. Unemployment puts downward pressure on wages, while oil prices push them up.

The dynamics of the stock market are determined by a combination of inflation, money and productivity growth, and real wages. ${ }^{17}$ In particular, while the growth rate of real money balances $\left(\mu_{t}-\pi_{t}\right)$ affects positively the stock market, an increase in money growth depresses it. Note that since prices satisfy the money neutrality condition, inflation equals

\footnotetext{
${ }^{14}$ Note that we only report the OLS estimates - 3SLS estimation is not feasible as we run out of degrees of freedom due to the large number of instruments required in the context of such a big model.

${ }^{15}$ The restriction that the long-run elasticity of prices with respect to wages is unity cannot be rejected by the Wald test at the $2.3 \%$ significance level.

${ }^{16}$ The restriction is imposed by setting equal to unity the long-run elasticity of wages with respect to its nominal determinants (i.e. prices and money supply). The restriction cannot be rejected at the $5 \%$ significance level using the Wald test.

${ }^{17}$ Although the equation was initially estimated having these variables as separate regressors, the signs and magnitudes of their coefficients eventually led to the selected specification given in Table 2.
} 
money growth in the long-run. Thus, our equation implies that an increase in inflation has a negative impact on the performance of the stock market.

Furthermore, the (financial wealth) equation includes the growth in productivity rather than its level. This implies that productivity does not influence the stock market in the long-run, which is consistent with the finding by Madsen and Philip Davis (2006, p.791) that "productivity advances can only have temporary effects on the fundamentals of equity prices.' Finally, the disparity between productivity and real wages, the so called wage-gap, has a positive effect on the stock market. Our interpretation is that this variable proxies the profit rate so that the more real wages lag behind productivity, the higher is the firm's profitability and the higher its market value.

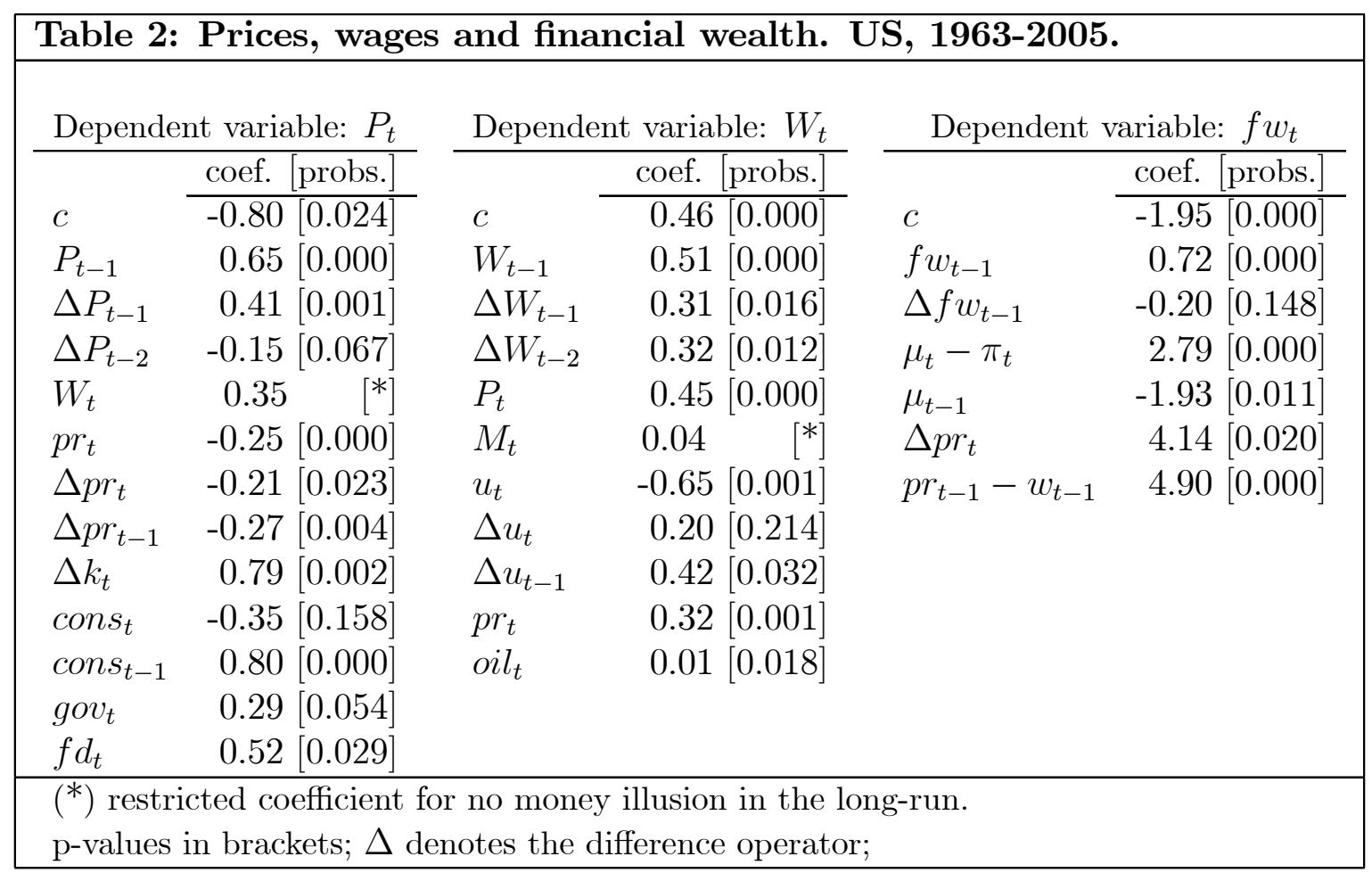

The employment equation reflects a standard downward sloping labour demand curve with a long-run wage elasticity equal to -0.72. Since this is below unity in absolute value, wage increases are not fully translated into employment reductions. Real balances, capital stock and productivity shift the labour demand outwards and enhance employment, at a given wage, with long-run elasticities ranging from 0.32 to 0.40 . Finally, indirect taxes have the expected negative influence. ${ }^{18}$

In the labour force equation, wages have an overall negative influence on labour supply decisions, while the tax variables display a positive coefficient. The traditional justification of the influence of wages via the relative weight of the income and substitution effects is

\footnotetext{
${ }^{18}$ Although this variable is not statistically significant at conventional levels, it improves the overall specification and diagnosis of the equation.
} 
unsatisfactory at the macro level. Nevertheless, Lin (2003) shows that when working hours and work effort are treated as different variables (unlike in the textbook classical model) two substitution effects may arise and explain a backward-bending labour supply. This is related with the impact of taxes on labour supply decisions in a labour market, such as the US one, where a large share of workers possess a slim income share. In this case, better wages allow a reduction in the supply of labour, while higher taxes harden the economic conditions of households and force them to supply more work. ${ }^{19}$

The performance of the stock market enters the labour force equation with a small coefficient and the expected negative sign. This is along the lines of Phelps (1999), who was the first to draw attention to the role played by financial wealth in the US labour market. Finally, unemployment discourages participation, while working-age population (capturing demographic and migration influences) indicates that population has a positive effect on labour supply.

\begin{tabular}{|c|c|c|c|c|c|}
\hline \multicolumn{2}{|c|}{ Dependent variable: $n_{t}$} & \multicolumn{2}{|c|}{ Dependent variable: $l_{t}$} & \multicolumn{2}{|c|}{ Dependent variable: $p r_{t}$} \\
\hline & coef. [probs.] & & coef. [probs.] & & coef. [probs.] \\
\hline$c$ & $2.89[0.004]$ & $c$ & $-1.52[0.014]$ & $c$ & $3.11[0.167]$ \\
\hline$n_{t-1}$ & $0.75[0.000]$ & $l_{t-1}$ & $0.69[0.000]$ & $p r_{t-1}$ & $0.64[0.000]$ \\
\hline$w_{t}$ & $-0.18[0.033]$ & $w_{t}$ & $0.05[0.299]$ & $n_{t}$ & $-0.21[0.062]$ \\
\hline$M_{t}-P_{t}$ & $0.09[0.001]$ & $w_{t-1}$ & $-0.10[0.009]$ & $k_{t}$ & $0.19[0.107]$ \\
\hline$k_{t}$ & $0.10[0.058]$ & $\tau a x_{t}^{s s}$ & $-0.21[0.452]$ & $\Delta k_{t}$ & $1.38[0.000]$ \\
\hline$\Delta k_{t}$ & $1.66[0.000]$ & $\tau a x_{t-1}^{s s}$ & $0.74[0.009]$ & $\Delta k_{t-1}$ & $-1.50[0.000]$ \\
\hline$\Delta k_{t-1}$ & $-1.33[0.000]$ & $\operatorname{tax}_{t}^{d}$ & $0.15[0.011]$ & $\Delta k_{t-2}$ & $0.54[0.055]$ \\
\hline$p r_{t}$ & $-0.16[0.112]$ & $\operatorname{tax}_{t}^{i}$ & $-0.55[0.034]$ & $\mathrm{oil}_{t}$ & $-0.01[0.005]$ \\
\hline$p r_{t-1}$ & $0.24[0.034]$ & $\operatorname{tax}_{t-1}^{i}$ & $0.61[0.026]$ & $t$ & $-0.07[0.896]$ \\
\hline \multirow[t]{5}{*}{$\operatorname{tax}_{t}^{i}$} & $-0.50[0.353]$ & $f w_{t}$ & $-0.01[0.001]$ & $t^{2}$ & $0.007[0.065]$ \\
\hline & & $u_{t}$ & $-0.27[0.000]$ & & \\
\hline & & $z_{t}$ & $0.40[0.000]$ & & \\
\hline & & $\Delta z_{t}$ & $0.47[0.004]$ & & \\
\hline & & $\Delta z_{t-1}$ & $-0.23[0.061]$ & & \\
\hline
\end{tabular}

The last equation models productivity as a function of the standard production factors. Thus, labour productivity depends negatively on employment, and positively on capital stock availability and quicker technological change (proxied by time trends). The negative elasticity of oil prices accounts for the influence of raw materials, an often overlooked production factor. The "global" long-run semi-elasticity of unemployment with respect to oil

\footnotetext{
${ }^{19}$ This situation of regressive taxation fits with the evidence provided by Hamermesh (2006) on low paid employees and over-time work. In particular, he points to the disproportionately amount of work performed in the US 'by low-wage workers, at unusual times - evening/nights and weekends.'
} 
prices, obtained by the IRFs of the system, is 0.014 - a $1 \%$ increase in oil prices leads to a 1.4 percentage points increase in the unemployment rate.

Figure 1 displays the actual and fitted values of the unemployment and inflation rates. Note that our estimated model tracks the data very well, despite its relatively large size and the plethora of feedback mechanisms.

Figure 1. Actual and fitted values

a. Unemployment

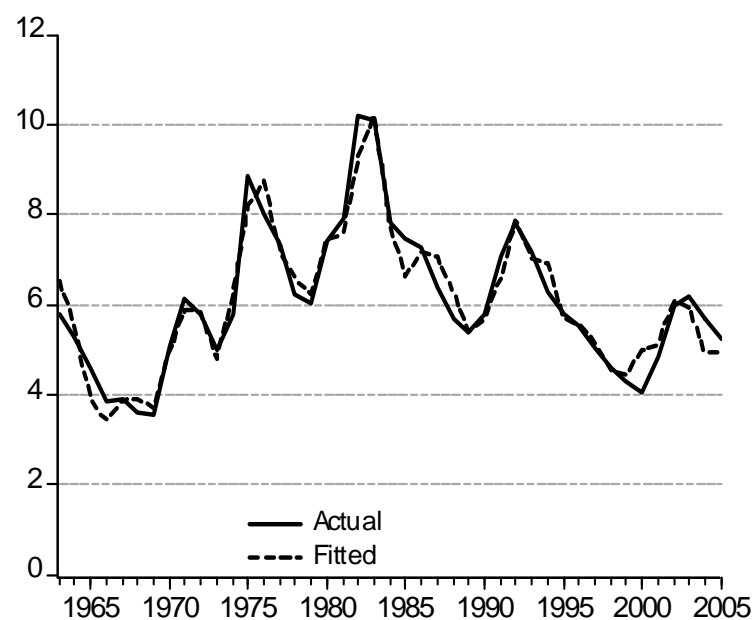

b. Price inflation

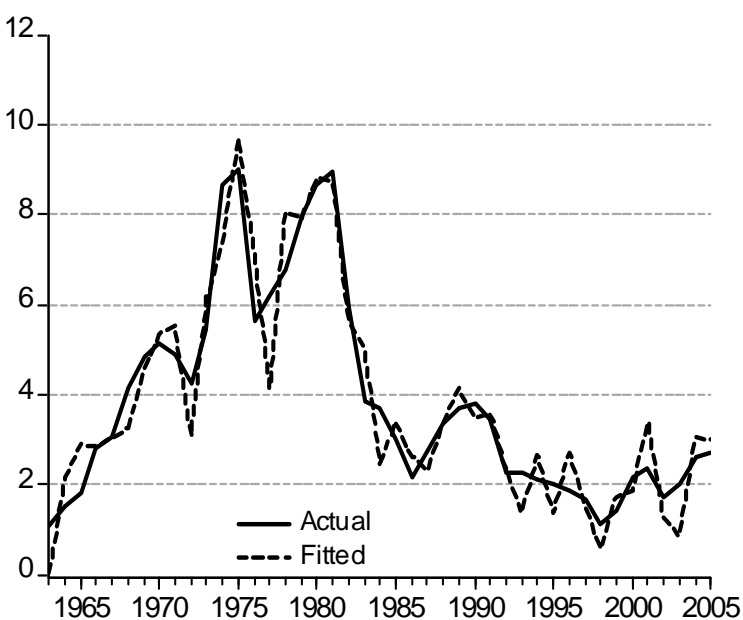

\section{The Long-run Phillips Curve Tradeoff}

In what follows, we describe monetary policy in terms of the growth rate of the money supply $\left(\mu_{t}\right)$. This has an obvious advantage when examining the long-run Phillips curve: to identify different points on the long-run Phillips curve, we need to identify different longrun inflation rates and these are associated with different long-run money growth rates. In the literature, for example, Cooley and Hansen (1989), Cooley and Quadrini (1999), Chari, Kehoe, and McGrattan (2000), and Mankiw and Reis (2002) assume that the monetary policy shock is the error in the time series representation of money growth.

We regard money growth as a better indicator of the overall monetary conditions than the federal funds rate, since it reflects not only the level of the yield curve (i.e. short-term interest rate), but also its slope (i.e. spread) and curvature (i.e. relative spread). It is widely accepted that the shape of the yield curve is influenced by expected future spot rates which, in turn, are influenced by monetary policy. For example, the higher spreads of the 1980s were accompanied by a monetary contraction (a decrease in money growth). In the second half of the 1990s the funds rate was relatively stable, while the flattening of the yield curve was associated with a monetary expansion. Furthermore, increases (decreases) 
in the short-term rate do not always translate to monetary contractions (expansions). For example, the increase in the fund rate from 3\% in 1993 to $6 \%$ in 1995 was associated with an increase in money growth from $1.5 \%$ to $4 \%$, and robust economic growth. Finally, money growth captures the fluctuations in the liquidity of the market. For example, after the 1987 stock market crash, the Fed provided additional reserves to the banking system to prevent a liquidity squeeze (Taylor, 1993). Following the 1988-89 crisis in the savings and loan (S\&L) industry, banks restricted their lending to conform to new regulations that would minimise the chances of another crisis and bailout in the future. The Fed's decision to treat long-term government bonds as if they were perfectly safe (despite their high sensitivity to interest rate changes) encouraged banks to invest in these bonds rather than lend to business, and thus further precipitated the 1991 recession (Stiglitz, 2003, p. 40).

In accordance with the aim of this paper we evaluate the effects of monetary policy on unemployment and inflation. In particular, we evaluate the slope of the Phillips curve by introducing an unanticipated permanent shift in money growth, say from 0 to $10 \%$ at $t=0$, and simulating the empirical model until the variables stabilise in the longrun. ${ }^{20}$ The inflation and unemployment IRFs are plotted in Figure 2a. In accordance with stylised facts (see, among others, Mankiw 2001), the responses are delayed and gradual, with unemployment adjusting faster than inflation.

Figure 2. Impulse response functions to a permanent increase in money growth

a. Price inflation and unemployment

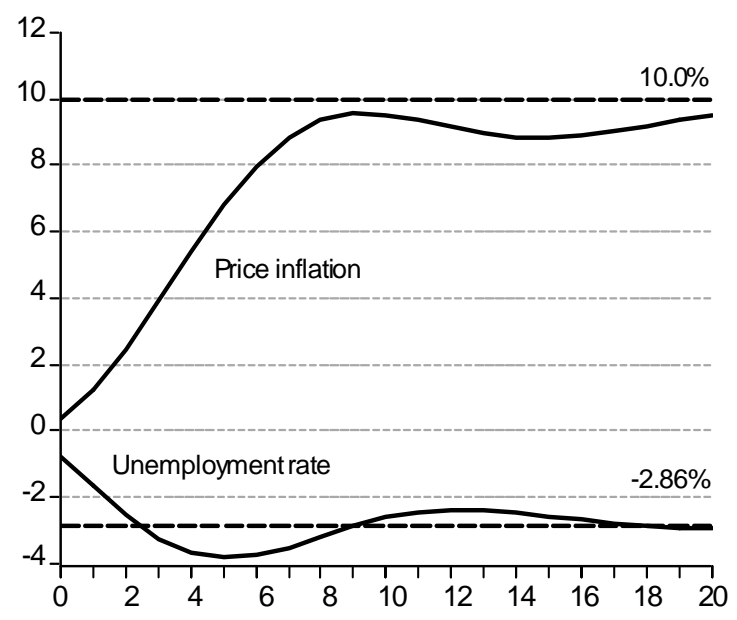

b. Price/wage inflation and real wage growth

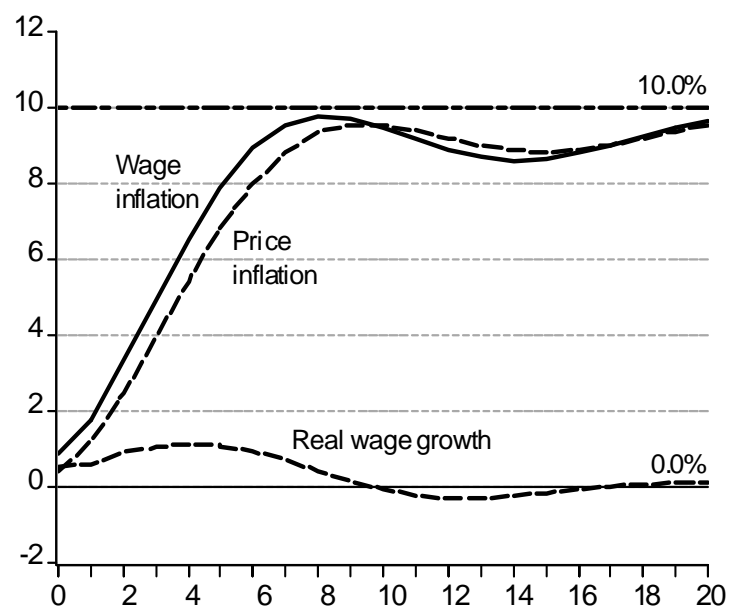

Due to money neutrality, price (and wage) inflation stabilises at $10 \%$ in the long-run. The only unconventional feature of the IRFs is that the unemployment effects of the monetary

\footnotetext{
${ }^{20}$ Since the residuals of our structural model are uncorrelated with changes in money growth, we are justified to assume that there are no other shocks to the model. Note that this is the counterpart of the standard assumption in vector autoregressions (VARs) of zero covariances between the structural innovations.
} 
shock do not dissipate with the passage of time. Instead, unemployment decreases by 2.86 percentage points in the long-run, implying that the long-run slope of the $\mathrm{PC}$ is $\frac{10}{-2.86}=-3.5$. This is very close to the long-run slope of -3.66 that Karanassou, Sala, and Snower (2005) found using a three-equation CRT model for the US from 1966 to 2000. Furthermore, as shown in Figure 2b, wage inflation adjusts faster than price inflation and the real wage growth rate is procyclical.

\section{A Reappraisal of the Roaring Nineties}

The literature has focused on two main explanations of the roaring nineties: (i) low inflation expectations (given the strong emphasis placed on inflation control by the Fed in the 1980s) together with a declining time-varying NAIRU; and (ii) the New Economy (i.e., the extensive and intensive development of information and communication technologies), that would explain the fast productivity growth witnessed in the 1990s and the resulting inflation deceleration. ${ }^{21}$ In addition, the discretionary monetary policy by Alan Greenspan has been widely appreciated (see Friedman, 2006, and Phelps, 2006).

In this section we use the above estimated model to reappraise the roaring nineties and explain the absence of inflationary pressures (inflation was hovering around $2 \%$ ) in the face of a rapid unemployment decline (unemployment fell from around 8\% to 4\%). In particular, our analysis examines the influence of higher productivity growth, increase in money growth, contractionary fiscal policy, and explosion of the trade deficit on the unemployment and inflation trajectories from 1993 to 2000. We evaluate the contributions of each of these factors by plotting the actual series of inflation (unemployment) against its simulated series obtained by fixing each specific factor at its 1993 value (see Figure 3). The disparity between the actual and simulated series of inflation (unemployment) measures the dynamic contribution of the specific factor to inflation (unemployment).

Our analysis indicates that higher productivity growth, the monetary expansion, a fiscal policy aiming at reducing the public deficit, and the rising trade deficit significantly contributed to prevent an inflation upsurge without seriously damaging employment.

\footnotetext{
${ }^{21}$ Along these lines, Gordon (1998) provides a list of candidates responsible for the decline in the NAIRU; Staiger, Stock and Watson (2002) discuss the right estimate of the NAIRU in the second half of the 1990s; Ball and Moffit (2002) focus on the effects of productivity growth on the Phillips curve; Greenspan emphasized on many occasions that the New Economy was bringing with it a new era of productivity increases (Stiglitz, 2003, p. 66).
} 
Figure 3. Actual and 1993 values of the exogenous variables

a. Productivity growth

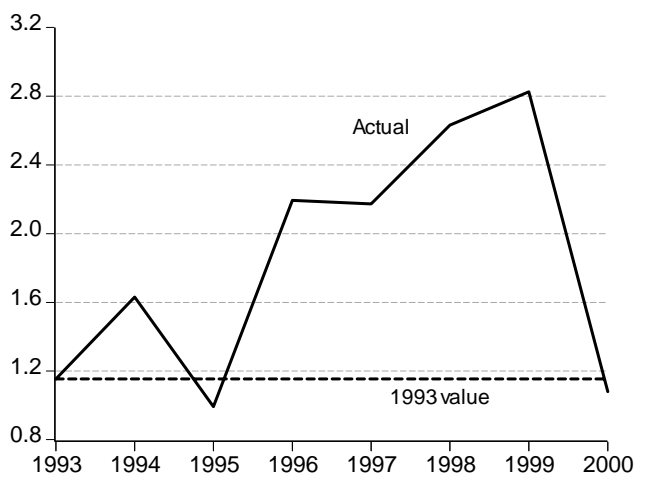

c. Public expenditures

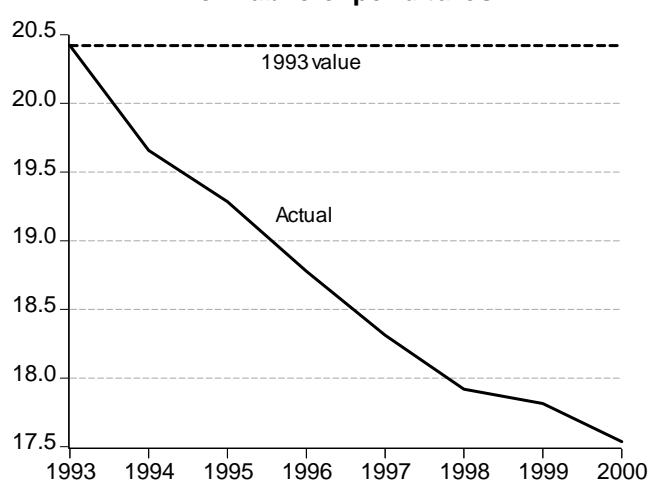

e. Indirect taxes

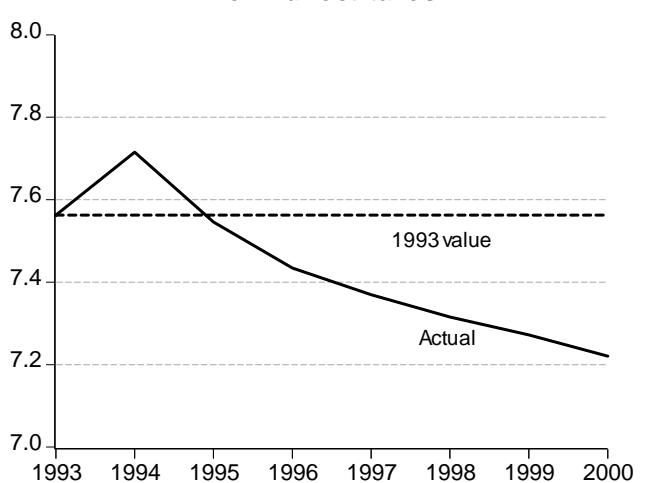

g. Budget deficit

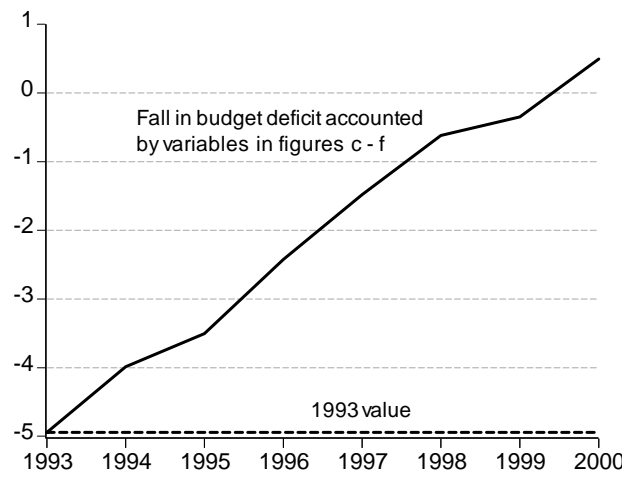

b. Money growth

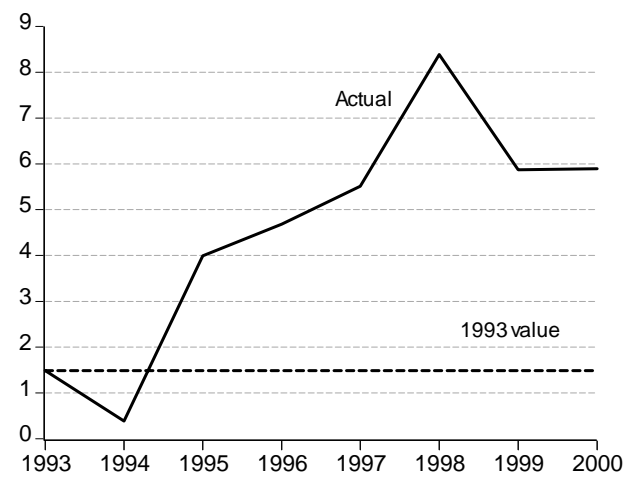

d. Direct taxes on households

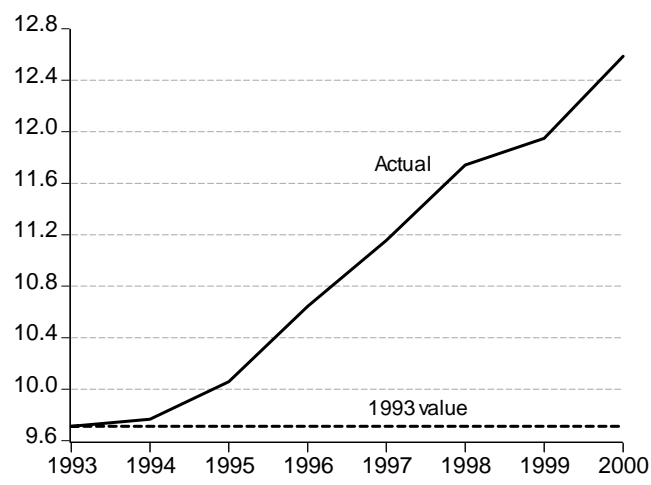

\section{f. Social security contributions}

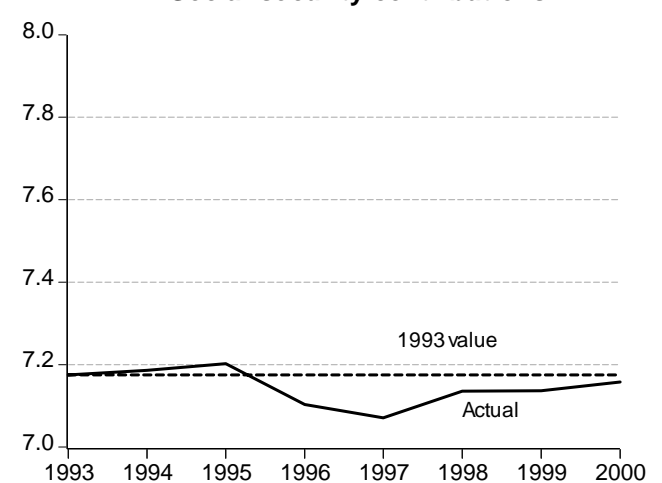

g. Trade deficit

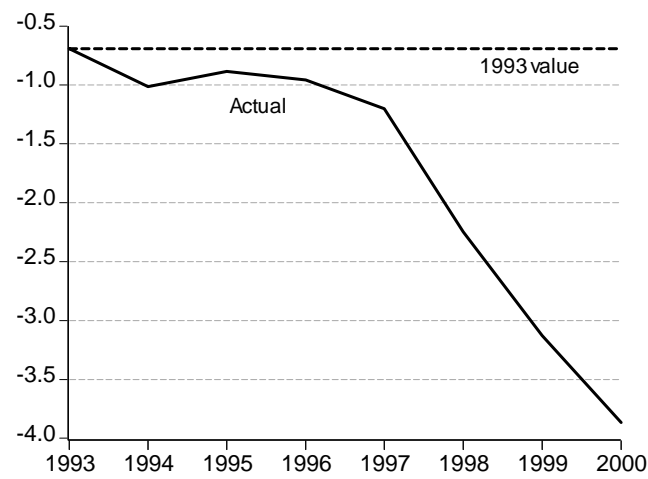




\subsection{Productivity Growth}

The role that the increase in productivity growth played on the positive performance of the US economy has received great attention in recent years. For example, Ball and Moffit (2002) argue that this increase caused a favourable shift of the Phillips curve. According to Blinder and Yellen (2002), the rise in productivity growth is a key supply-side shock. Although Staiger, Stock and Watson (2002) support the view that a declining NAIRU is the driving force of the roaring nineties, they also argue that the higher productivity growth led to a shift in the PC.

As Figure 3a shows, productivity growth increased from $1.1 \%$ in 1993 to $2.8 \%$ in 1999 with the break in its trend occurring in 1995-96. ${ }^{22}$ According to Blinder and Yellen (2002, p. 62), the rise in productivity growth was mainly due to (i) the increased productivity of the computer industry, (ii) capital deepening, i.e. the expanded use of computers in the economy, and (iii) advances in information technology, boosting productivity in the computer intensive sectors of the market.

Figure 4. Contributions of productivity growth

\section{a. Unemployment}

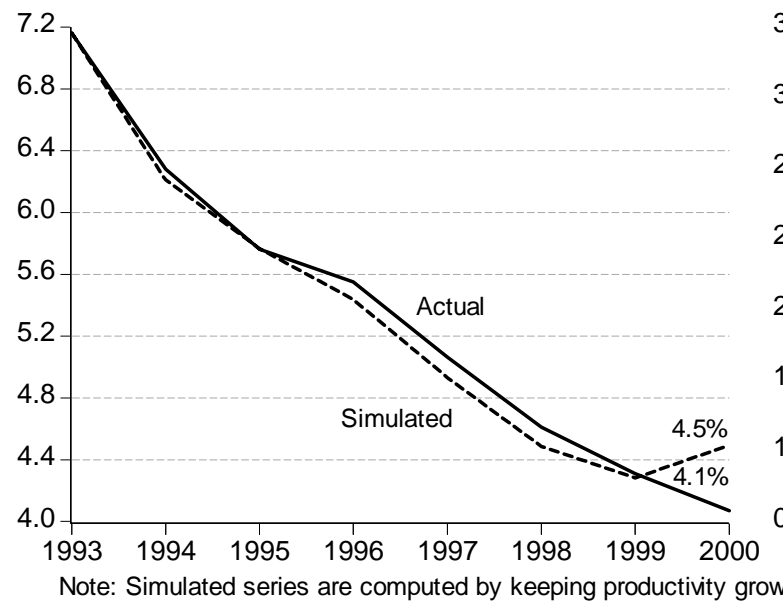

b. Inflation

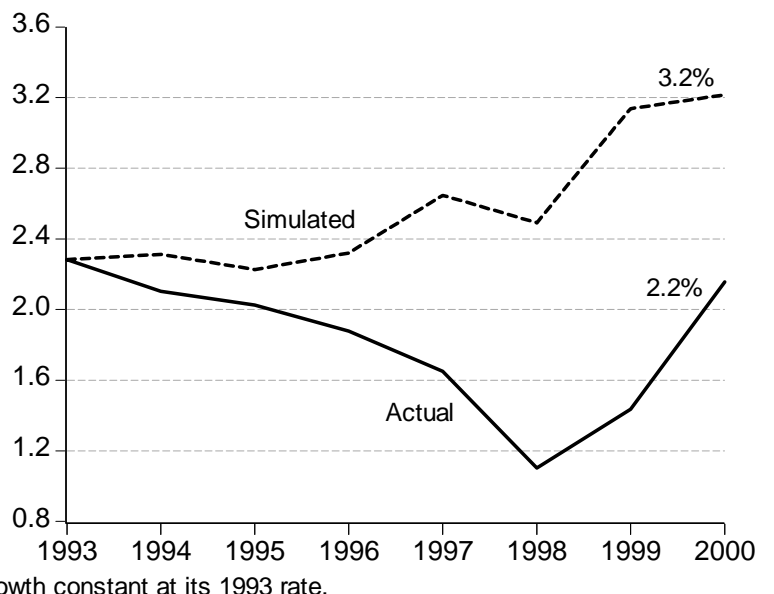

Despite productivity being an endogenous variable in our model, we account statistically for the effects of productivity growth by holding it constant at its 1993 value in the simulated model and comparing the resulting time paths of inflation and unemployment with the time paths associated with the actual time series of productivity growth. Needless to say, this is simply an accounting exercise and it should be interpreted with caution. The actual and simulated series of unemployment and inflation are plotted in Figure 4. Observe that,

\footnotetext{
${ }^{22}$ See also Blinder and Yellen (2002, p. 59).
} 
the productivity increase put substantial downward pressure on inflation - had productivity growth remained at its 1993 value, inflation would have reached $3.2 \%$ in 2000, instead of the actual $2.2 \%$. In addition, a modest reduction in unemployment took place by the end of the decade (unemployment would have risen to $4.5 \%$ in 2000 instead of the realised $4.1 \%$ ).

\subsection{Monetary Policy}

Money growth rose steadily from $1.5 \%$ in 1993 to $8.4 \%$ in 1998 to read almost $6 \%$ in 1999 2000 (see Figure 3b). The monetary expansion of the 1990s substantially reduced unemployment and put upward pressure on inflation. ${ }^{23}$ As shown in Figure 5, had money growth stayed at its 1993 value, unemployment would have remained approximately constant and close to $6 \% 1995$ onwards. In turn, the growth of prices would have declined attaining a situation of deflation at the end of the decade. In short, the contributions of money growth and inflation amounted to a fall of approximately 2 percentage points in unemployment, and a rise of around 3 percentage points in inflation.

Figure 5. Contributions of monetary policy

a. Unemployment

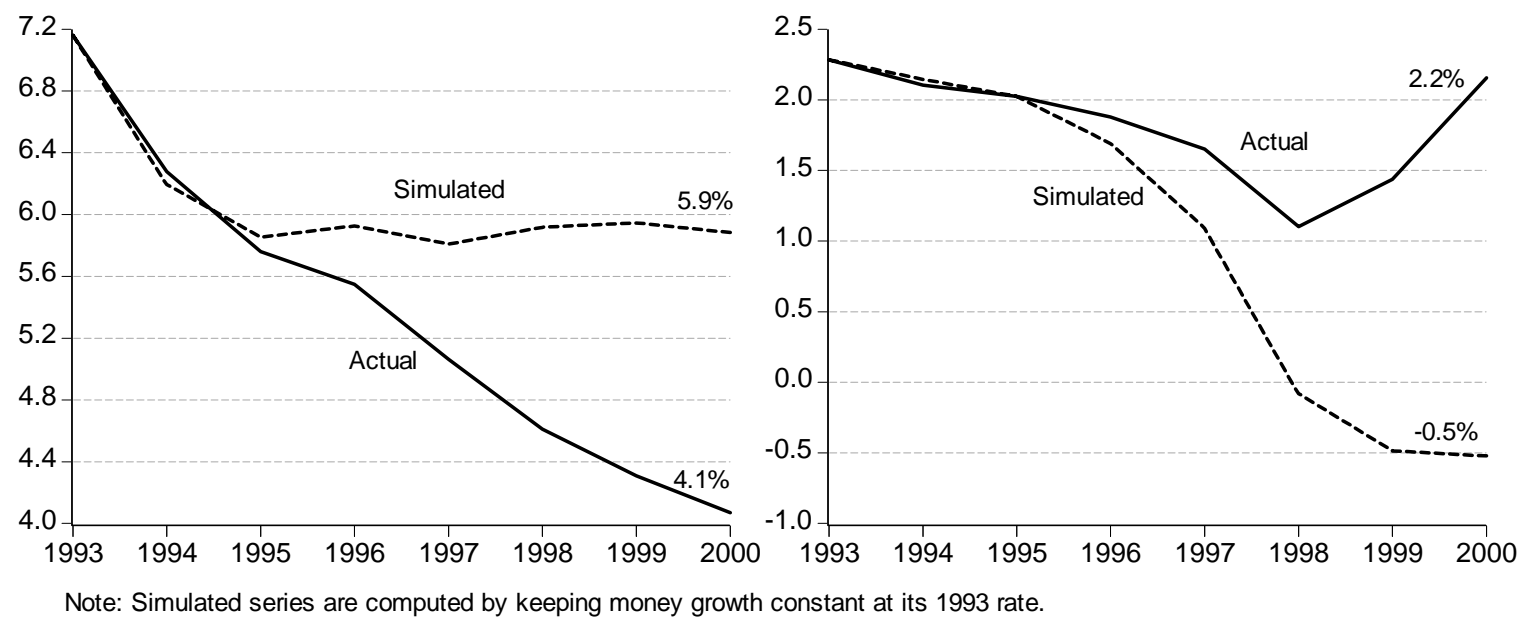

Conventional macro models - built on the assumption that the Phillips curve becomes vertical once inflationary expectations and nominal contracts have adjusted to actual inflation - have had difficulty explaining why monetary policy should have had a significant influence on US unemployment in the 1990s. Our model does so by suggesting that the substantial influence stems in part from a long-run relation between unemployment and money growth. Yet the flip side of this favorable development, as mentioned, was an associated

\footnotetext{
${ }^{23}$ Blinder and Yellen (2002, p.12-13) refer to the monetary expansion by saying that '...until February 1994...the real funds rate was kept around zero for about a year and a half - providing an extraordinary dose of easy money' and argue that this 'is important to understanding what made the 1990s roar.'
} 
threat of increased inflation. Our analysis indicates that two powerful forces contributed to push inflation down: (i) fiscal policy aiming at reducing the public deficit and (ii) the rising trade deficit.

\subsection{Fiscal Policy}

The budget deficit was balanced in the Clinton years to increase again in the early 2000s. In 1993 it was $4.9 \%$ of GDP (it had reached a maximum of $5.8 \%$ in 1992) and continued to fall steadily, turning into a budget surplus by the end of the decade (see Figures 3c-g). The reduction of around 6 percentage points in the budget balance over the 1993-2000 period was achieved by reducing government expenditures and increasing direct taxes by approximately 3 percentage points each, so that, as Stiglitz (2003, p. 48) put it 'The cost of adjustment would be shared.' (Indirect taxes and social security contributions as percentage of GDP remained approximately constant during that period.) According to Blinder and Yellen (2002, p. 16), the deficit reduction program was put forward to prevent the occurrence of a financial calamity (mostly feared by Wall Street), and thus "saving jobs". The spirit of this policy was essential anti-Keynesian, since it aimed at increasing employment by cutting government expenditures and raising taxes.

Figure 6. Contributions of fiscal policy

a. Unemployment

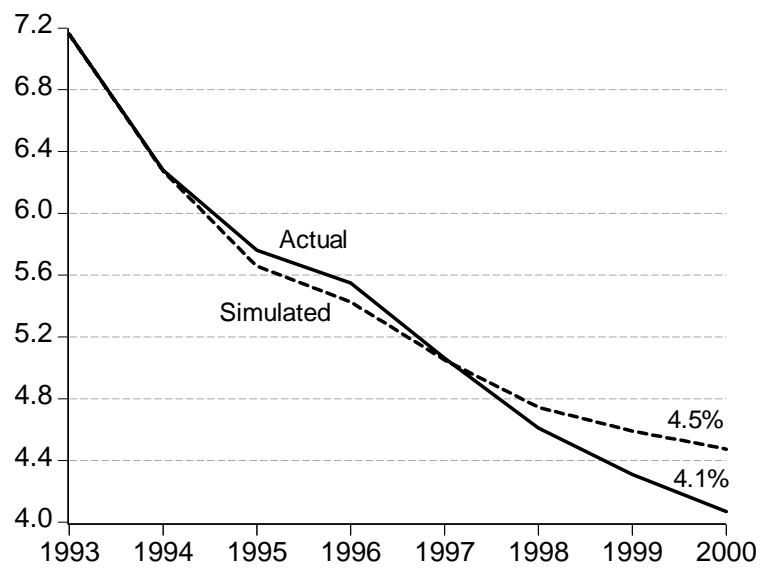
expenditures constant at their 1993 values.

Our analysis shows (see Figure 6) that closing the budget gap put substantial downward pressure on inflation without leaving a heavy footprint on the unemployment rate. (Recall that the simulated series in Figure 6 were obtained by assuming that the budget deficit had remained at its 1993 value until 2000.) In other words, deficit reduction per se was 
not responsible for the economic recovery witnessed during the 1990s. However, it is widely accepted that the deficit reduction led to lower long-term interest rates which, in turn, contributed to the monetary expansion experienced throughout the decade. As shown in Figure 5, it was the resulting increase in money growth that paved the way for creating jobs. Our findings support Stiglitz (2003, p. 42) who argues that 'By lowering the deficit, the Clinton administration ended up recapitalizing a number of American banks; it was this inadvertent act, as much as anything, that refueled the economy.'

\subsection{Trade Deficit}

The trade deficit is a standard feature of the US economy: from 1960 to the mid 1990s the gap between exports and imports as a percent of GDP was fluctuating around -1\% (see Figure $3 \mathrm{~h}$ ). In the second half of the nineties, however, and in particular after the 1997 East-Asian crisis, it started to increase steadily reaching $3.9 \%$ in 2000. As shown in Figure 7, the larger trade deficit, similarly to the budget deficit reduction, put substantial downward pressure on inflation without affecting much unemployment. Note that the substantial decrease in inflation essentially takes place after the 1997 East-Asian crisis. This result is in line with the perception of the average business person that the relatively low inflation rates experienced in recent years are due to cheap imports from the Far East and Eastern Europe (Bean, 2007). Furthermore, the negative relationship between openness (measured by the ratio of imports to GDP) and inflation is well documented in the literature (e.g. Temple, 2002).

Figure 7. Contributions of trade deficit

a. Unemployment

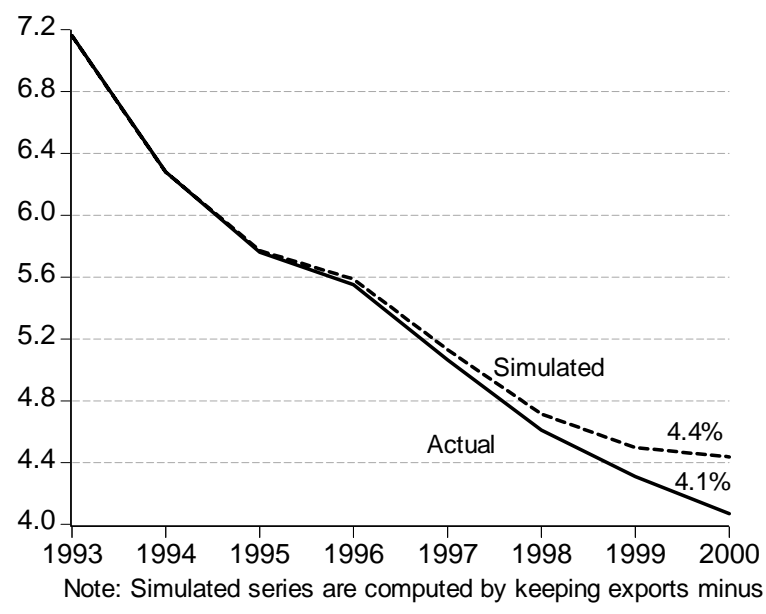

b. Inflation

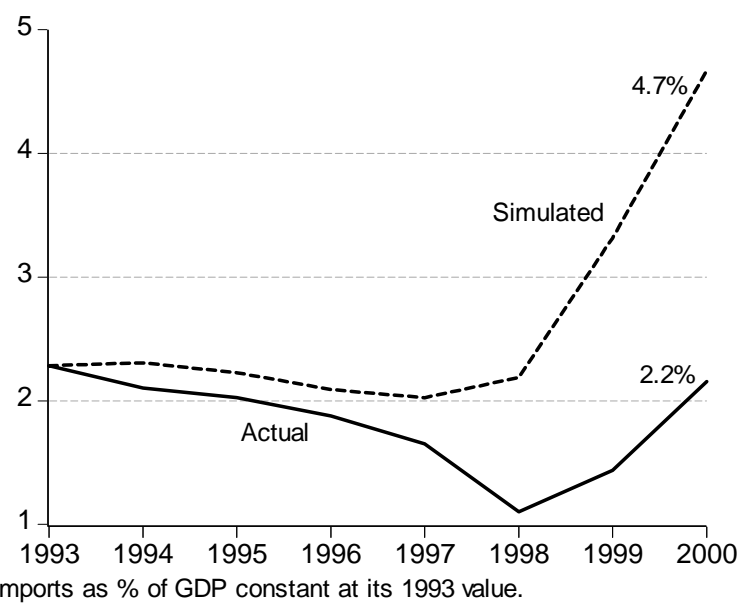

Overall, the simulations in Figures 4-7 indicate that the decrease in the budget deficit and the increases in productivity growth and the trade deficit kept inflation low while the 
economy was operating at relatively low unemployment rates. In contrast, several policy makers and academics have argued that this was due to higher levels of education, weaker unions, a more competitive marketplace, increased productivity, and a slower influx of new workers (see, for example, Stiglitz, 2003, p. 72).

\section{Methodological Issues: GMM and SVARs}

In what follows we demonstrate the robustness of the finding of a downward-sloping PC in the long-run. In particular, we provide a brief assessment of the generalised method of moments (GMM) and structural vector autoregressions (SVARs) vis-à-vis our econometric methodology of structural modelling, and show that a long-run inflation-unemployment tradeoff can also be obtained by applying these econometric techniques.

\subsection{GMM Single-equation Estimation of the PC}

We start by evaluating the inflation-unemployment tradeoff using the GMM in the context of the popular new (Keynesian) Phillips curve, NPC. Despite the lack of general consensus on the exact specification of the NPC, it is commonplace to use the following hybrid form:

$$
\pi_{t}=\beta^{f} E_{t} \pi_{t+1}+\beta^{b} \pi_{t-1}+\gamma^{\prime} x_{t}
$$

where $x_{t}$ is a column vector of forcing variables that includes a measure of excess demand (unemployment rate, output gap) or a measure of real marginal costs (such as the labour share in GNP), $E_{t}$ denotes conditional expectations, and the $\beta \mathrm{s}$ and $\gamma \mathrm{s}$ are constants.

Following standard practice, expected future inflation is proxied by the lead of inflation and the above NPC is rewritten as

$$
\pi_{t}=\beta^{f} \pi_{t+1}+\beta^{b} \pi_{t-1}+\gamma^{\prime} x_{t}+\epsilon_{t+1},
$$

where the expectational error $\epsilon_{t+1}$ is proportional to $\left(E_{t} \pi_{t+1}-\pi_{t+1}\right)$, and is unforecastable at time $t$ under rational expectations. Much of the current literature is concerned with the question of whether the observed inflation autocorrelation results from backward-looking behaviour $\left(\beta^{f}=0\right)$ or forward-looking behaviour $\left(\beta^{b}=0\right)$ that is proxied by inflation lags.

Using a set of variables $z_{t}$ (dated $t$ and earlier) to instrument actual future inflation $\pi_{t+1}$, the NPC specification (24) can be consistently estimated by GMM or two-stage least squares. ${ }^{24}$ It is widely recognised that the empirical results of (24) are sensitive to (i) the choice and exact implementation of the estimation method, (ii) the forcing variables, (iii) the list of instruments, and (iv) the time span of the instruments, i.e. whether they are

\footnotetext{
${ }^{24} \mathrm{GMM}$ requires the orthogonality condition $E_{t}\left[\left(\pi_{t}-\beta^{f} \pi_{t+1}-\beta^{b} \pi_{t-1}-\gamma^{\prime} x_{t}\right) z_{t}\right]=0$.
} 
dated $t$ and earlier or $t-1$ and earlier. Furthermore, the exogeneity/endogeneity of the driving variables $x_{t}$ is of major importance. Bårdsen, Jansen and Nymoen (2004) argue that the derivation of the dynamic properties of inflation necessitates the analysis of a system that includes the forcing variables as well as the rate of inflation, and conclude that the NPC (24) is inadequate as a statistical model.

Although estimation of the Phillips curve with GMM is typically carried out with quarterly data, we use semi-annual time series to ensure that our standard hybrid single-equation PCs are free of $(\mathrm{G}) \mathrm{ARCH}$ effects. The sample period is 1963:1-2005:2, and the variables included in our regressions are covariance stationary, $\mathrm{I}(0)$, according to KPSS tests. (These results are available upon request.)

\begin{tabular}{|c|c|c|c|c|c|c|c|}
\hline \multicolumn{8}{|c|}{$\begin{array}{l}\text { Table 3. Phillips curve GMM estimates, 1963:1 - 2005:2 } \\
\text { Dependent variable is } \pi_{t}\end{array}$} \\
\hline \multicolumn{8}{|l|}{ Model 1} \\
\hline$c$ & $\pi_{t+1}$ & $\pi_{t-1}$ & $\pi_{t-2}$ & $u_{t}$ & $i m p_{t}$ & $R^{2}$ & slope \\
\hline $\begin{array}{l}0.008 \\
{[0.032]}\end{array}$ & $\begin{array}{l}0.274 \\
{[0.096]}\end{array}$ & $\begin{array}{l}0.481 \\
{[0.018]}\end{array}$ & $\begin{array}{l}0.213 \\
{[0.015]}\end{array}$ & $\begin{array}{c}-0.137 \\
{[0.024]}\end{array}$ & $\begin{array}{l}0.008 \\
{[0.049]}\end{array}$ & 0.918 & -4.32 \\
\hline \multicolumn{2}{|c|}{ Instruments: } & \multicolumn{5}{|c|}{$c, \pi_{t-1}, \pi_{t-2}, u_{t-1}, u_{t-2}, i m p_{t-1}, \mu_{t-1}$} & \\
\hline \multicolumn{2}{|c|}{ Validity of instruments: } & \multicolumn{2}{|c|}{ F-test $\left(\pi_{t+1}\right)=50.2$} & F-test $(u$ & $\begin{array}{r}=204.2 \\
{[0.000]}\end{array}$ & \multicolumn{2}{|c|}{$\chi^{2}(1)=0.07$} \\
\hline \multicolumn{8}{|l|}{ Model 2} \\
\hline$c$ & $\pi_{t+1}$ & $\pi_{t-1}$ & $\pi_{t-2}$ & $u_{t}$ & $i m p_{t}$ & $R^{2}$ & slope \\
\hline $\begin{array}{l}0.005 \\
{[0.002]}\end{array}$ & $\begin{array}{l}0.455 \\
{[0.000]}\end{array}$ & $\begin{array}{l}0.272 \\
{[0.015]}\end{array}$ & $\begin{array}{l}0.249 \\
{[0.001]}\end{array}$ & $\begin{array}{c}-0.084 \\
{[0.001]}\end{array}$ & $\begin{array}{l}0.006 \\
{[0.011]}\end{array}$ & 0.923 & -3.50 \\
\hline \multicolumn{2}{|c|}{ Instruments: } & \multicolumn{6}{|c|}{$c, \pi_{t-1}, \pi_{t-2}, u_{t-1}, u_{t-2}, i m p_{t-1}, \mu_{t-1}, u_{t}, i m p_{t}, \mu_{t}$} \\
\hline \multicolumn{2}{|c|}{ Validity of instruments: } & \multicolumn{2}{|c|}{ F-test $\left(\pi_{t+1}\right)=80.4$} & & & \multicolumn{2}{|c|}{$\chi^{2}(4)=\begin{array}{l}1.64 \\
{[0.802]}\end{array}$} \\
\hline \multicolumn{8}{|l|}{ Model 3} \\
\hline$c$ & $\pi_{t+1}$ & $\pi_{t-1}$ & $\pi_{t-2}$ & $u_{t}$ & $i m p_{t}$ & $R^{2}$ & slope \\
\hline $\begin{array}{l}0.004 \\
{[0.030]}\end{array}$ & $\begin{array}{l}0.456 \\
{[0.000]}\end{array}$ & $\begin{array}{l}0.273 \\
{[0.015]}\end{array}$ & $\begin{array}{l}0.247 \\
{[0.001]}\end{array}$ & $\begin{array}{c}-0.080 \\
{[0.023]}\end{array}$ & $\begin{array}{l}0.006 \\
{[0.054]}\end{array}$ & 0.923 & -3.30 \\
\hline \multicolumn{2}{|c|}{ Instruments: } & \multicolumn{6}{|c|}{$c, \pi_{t-1}, \pi_{t-2}, u_{t-1}, u_{t-2}, i m p_{t-1}, \mu_{t-1}, i m p_{t}, \mu_{t}$} \\
\hline \multicolumn{2}{|c|}{ Validity of instruments: } & \multicolumn{2}{|c|}{ F-test $\left(\pi_{t+1}\right)=83.8$} & F-test $\left(u_{t}\right.$ & $\begin{aligned} &= 158.7 \\
& {[0.000] } \\
&\end{aligned}$ & \multicolumn{2}{|c|}{$\chi^{2}(3)=1.64$} \\
\hline
\end{tabular}

Table 3 presents the results for three different GMM models. ${ }^{25}$ Further to the standard variables such as future inflation $\left(\pi_{t+1}\right)$, lagged inflation $\left(\pi_{t-1}, \pi_{t-2}\right)$, and unemployment

\footnotetext{
${ }^{25}$ All regressions are well-specified, and the F-statistics show a strong correlation between the lead of inflation $\left(\pi_{t+1}\right)$ and the set of instruments (see Staiger and Stock, 1997). Furthermore, the chi-square test for overidentifying restrictions (J-statistic times the number of observations) indicates the validity of the instruments.
} 
$\left(u_{t}\right)$, we also use import prices $\left(i m p_{t}\right)$ to capture external nominal influences on prices. In particular, this variable takes into account the movements in oil prices, as well as the prices of other imported goods and services (for example, imports from China and East-Asia) which in recent decades have become increasingly important for the US economy. ${ }^{26}$ Also note that the growth rate of money $\left(\mu_{t}\right)$ is added to the list of instruments containing current and lagged values of the explanatory variables.

In the first specification the instruments are dated $t-1$ and earlier, whereas in the second one they are dated $t$ and earlier. The third specification differs from the second one as it does not include current unemployment in the instruments list. All three models give rise to a downward sloping long-run Phillips curve. The inflation-unemployment long-run tradeoff ranges from -3.30 to $-4.32 .{ }^{27}$ Note that this tradeoffs are very close to the one we obtained via our structural modelling methodology. Finally, observe that in all three specifications the backward-looking behaviour has a stronger influence on inflation dynamics than the forward-looking behaviour.

\subsection{Reflections on Structural Models versus Vector Autoregres- sions}

Estimation of (dynamic) structural models involves the selection of the exogenous variables and the number of lags to be included in each equation of the system. Since these are mostly judgmental decisions, the methodology relies heavily on discretion rather than simple mechanical rules. On the other hand, the advantage of structural modelling (SM) is the economic intuition and plausibility that accompanies each of the estimated equations. SM has thus the potential of explaining the economic developments and can measure the contribution of the various exogenous variables to the evolution of the endogenous ones. The major drawback of the large macro-econometric models (simultaneous equations) of the past has been their misleading predictions, especially during the macroeconomic turbulence of the 1970s.

An important factor behind the quite often disastrous performance of the SM methodology is that, unless you have the IRFs with respect to the exogenous variables in the model, you do not know what the "global" short- and long-run elasticities are. The individual equations of the system only display the "local" short-run elasticities of an exogenous variable. The spillovers in the system can affect both the size and the sign of the elasticities. In Section 2 we demonstrated how to derive the global short- and long-run elasticities in an interactive dynamics model. These are essentially the initial and final values of the IRF

\footnotetext{
${ }^{26}$ The relationship between inflation and import prices is currently receiving close attention. See, for example, Bean (2007).

${ }^{27}$ However, we should stress that - as in the rest of the literature in this area - our estimates crucially depend on the specification of the driving variables and instruments.
} 
of an endogenous variable to a one-off unit change in a specific exogenous variable. The global elasticities can be used as a misspecification tool since they can diagnose the economic plausibility of the model. We believe that the lack of such diagnosis led to the demise of SM.

On the other hand, vector autoregressions (VARs) ${ }^{28}$ use an identical set of regressors and lag structure in the individual equations of the system, and their statistical toolkit is easy to use and interpret. In particular, they focus on the estimation of IRFs and variance decomposition. ${ }^{29}$ A reduced form VAR model regresses each variable on its own lags and the lagged values of the other variables in the model. Correlation between the different macro variables leads to cross-equation correlation that renders the calculation of IRFs problematic. When some contemporaneous values are added to the regressors list, the model is called a recursive VAR, and its estimation produces uncorrelated residuals. ${ }^{30}$ Therefore, VARs are associated with a minimal amount of discretion - the main modelling decision involves the ordering of the variables in the recursive model. Although there is hardly any economic intuition underlying the ordering of the variables, the estimation results crucially depend on it. The main advantage of the VAR methodology is that the overall influence of each variable on the rest of the system is gauged by the IRFs. However, VARs have been heavily criticized for their atheoretical (i.e. statistical rather than economic) nature.

Structural vector autoregressions (SVARs) addressed this critique by replacing the atheoretical identification of the VAR equations with an economic structure of the error terms. ${ }^{31}$ In other words, the SVAR methodology uses economic theory to decide on the contemporaneous correlations among the variables - hence, the "structural" adjective. ${ }^{32}$ The models are adjusted until they give "reasonable" impulse response functions. Following Leeper, Sims, and Zha (1996) this adjustment entails 'nothing unscientific or dishonest'.

We can classify the above econometric methodologies according to the degree of discretion involved in the estimation of the macro system. SM is at one end of the spectrum with a substantial amount of judgemental decisions, while VARs are at the other end with the minimal amount of discretion, and SVARs lie in between these two polar cases. The important lesson of the (structural) VAR literature is the use of impulse responses as a diagnostic tool of the plausibility of the macro-econometric model as a whole. Structural models that incorporate the IRF diagnosis have thus a main advantage over SVARs: the

\footnotetext{
${ }^{28}$ This macroeconomic framework was pioneered by Sims in 1980. See Stock and Watson (2001) for a brief and comprehensive tutorial.

${ }^{29}$ Note that the impulse (one-off shock) relates to the error term of a specific equation in the VAR model. In contrast, the impulse is a one-off change in a specific exogenous variable in the context of SM.

${ }^{30}$ Estimation of the recursive VAR is based on the estimation of the reduced form VAR and the Cholesky decomposition of its covariance matrix.

${ }^{31}$ See, among others, Leeper, Sims, and Zha (1996), Rudebusch (1998), Christiano, Eichenbaum, and Evans (1999, 2005), Raddatz and Rigobon (2003), Dedola and Lippi (2005), and Ribba (2007).

${ }^{32}$ Note that a structural VAR may simplify to a recursive VAR - this structure is known as a Wold causal chain.
} 
economic substance of the relations embedded in the macro system.

The lack of attention to the individual equations of the (S)VAR model (estimated VAR coefficients go unreported) is due to the fact that (S)VAR equations do not have an economic interpretation. However, the interest equation in a monetary (structural) VAR model has a clear economic interpretation - it is the reaction function of the Fed (or central bank). Rudebusch (1998) argues that the shortcomings of the typical (S)VAR interest rate equation are a time-invariant linear structure, a restricted information set, the use of revised data, and long distributed lags. These features suggest that the standard VAR reaction function misrepresents endogenous monetary policy. ${ }^{33}$ Furthermore, Rudebusch (1998) suggests that (S)VARs should be improved by giving more weight to economic structure, and is critical of modelers who, under the excuse of "atheoretical econometrics", skip the standard misspecification tests.

On the other hand, Leeper, Sims, and Zha (1996) argue that it is possible to construct economically interpretable SVAR models with superior fit to the data. However, Bernanke comments (in Leeper, Sims, and Zha, 1996, p. 69.) that by paying attention to identification, and thus becoming sophisticated, the new generation of VARs has 'moved closer to the complex econometric models that were the subject of Sims's original critique.' In addition, 'Mankiw found it ironic that Sims, who had developed the VAR methodology to diminish the extent to which macroeconomic models rely on a tremendous number of what he had called incredible identifying assumptions on the structure, has, with his coauthors, had to return to making many similar assumptions in order to identify policy effects.' (in Leeper, Sims, and Zha, 1996, p. 74.)

\subsection{SVAR Estimation of the Inflation-Unemployment Tradeoff}

Since Bernanke and Blinder (1992), monetary VARs regard the federal funds rate as the best reflection of US monetary policy and thus disentangle its endogenous and exogenous components by regressing the short-term interest rate on its own lags and the lags, and possibly contemporaneous values, of the other variables in the model. ${ }^{34}$ However, as we argued in Section 4, we believe that the overall monetary conditions of the economy are better described by the growth rate of a monetary aggregate than by a short-term interest rate.

Therefore, since our main objectives is to determine whether a long-run inflation-unemployment tradeoff arises when there is a permanent monetary expansion/contraction, we use a struc-

\footnotetext{
${ }^{33}$ Sims notes that the issues of structural stability, linearity, and variable selection are not unique to VARs, and thus the critique by Rudebusch applies to all macroeconomic models. See the interesting exchange between Sims and Rudebusch in the International Economic Review (1998), vol. 39.

${ }^{34}$ They argue that the federal funds rate provides a better measure of policy shocks than a monetary aggregate, since it is a good indicator of monetary policy and it 'is probably less contaminated by endogenous responses to contemporaneous economic conditions than is, say, the money growth rate.'
} 
tural VAR model that includes the unemployment rate, inflation, and money growth: ${ }^{35}$

$$
A_{0} y_{t}=\sum_{i=1}^{p} A_{i} y_{t-i}+\varepsilon_{t}
$$

where $y_{t}^{\prime}=\left(u_{t}, \pi_{t}, \mu_{t}\right)$, the $A$ s are $(3 \times 3)$ coefficient matrices. The $(3 \times 1)$ vector of error terms $\left(\varepsilon_{t}\right)$ has zero mean, constant variances, zero autocorrelations, and nonzero contemporaneous cross correlations:

$$
E\left(\varepsilon_{t}\right)=0, \text { and } E\left(\varepsilon_{t} \varepsilon_{s}^{\prime}\right)=\left\{\begin{array}{l}
C \text { for } t=s \\
0 \text { otherwise }
\end{array}\right\}
$$

A popular identification assumption used in the literature to recover the structural parameters, $A$ s and $C$, is the recursiveness assumption. This implies that the errors are orthogonal, $C=I$, and the matrix of contemporaneous relations between the variables in the VAR is lower triangular:

$$
A_{0}=\left[\begin{array}{lll}
a_{u u} & & \\
a_{\pi u} & a_{\pi \pi} & \\
a_{\mu u} & a_{\mu \pi} & a_{\mu \mu}
\end{array}\right]
$$

Essentially the above identification scheme assumes that monetary developments take place contemporaneously with changes in the unemployment and inflation rates, while these variables react to monetary changes only with a lag. In other words, the monetary shock is orthogonal to these variables. Christiano, Eichenbaum, and Evans (1999) refer to this as the recursiveness assumption. ${ }^{36}$ It can be shown that this assumption, although not enough to identify the reactions of the variables to all the structural shocks, is sufficient to determine the responses of the macro variables to a monetary expansion or contraction. An appealing feature of the recursive identifying approach is that the ordering of the variables preceding (and following) the monetary variable does not affect the estimation of their IRFs to the monetary shock.

Estimation of the structural VAR model (25)-(27) gives the impulse response functions plotted in Figure 8. ${ }^{37}$

Observe that the responses of unemployment and inflation are hump-shaped with peak effects occurring after 1.5-2 years and 2-3 years, respectively. Also note that the above

\footnotetext{
${ }^{35}$ This is analogous to the three-variable VAR model of inflation, unemployment, and the federal funds rate used by Stock and Watson (2001).

${ }^{36}$ Note that, while the recursiveness assumption is controversial, alternative identifying approaches are debatable as well. Furthemore, Christiano, Eichenbaum, and Evans (1999) explain that the adoption of alternative identification schemes does not necessarily imply that the monetary shock has a contemporaneous impact on unemployment and inflation.

${ }^{37} \mathrm{As}$ in the previous section, the dataset is semi-annual, and covers the period 1963.1-2005.2. Using the Akaike Information Criterion we selected a VAR of lag order four.
} 
model is free from the price puzzle (i.e. a monetary contraction leads to higher inflation) that characterised the IRFs of monetary VARS. ${ }^{38}$

Furthermore, variance decomposition analysis shows that around one third of the unemployment rate variation is explained by money growth, and the estimated parameters indicate that monetary policy is stabilising: a rise in unemployment increases money growth, while a rise in inflation decreases money growth (the slope coefficients are 0.52 and -0.49 , respectively). ${ }^{39}$

\section{Figure 8. Responses to one standard deviation innovations in money growth}

\section{a. Unemployment}

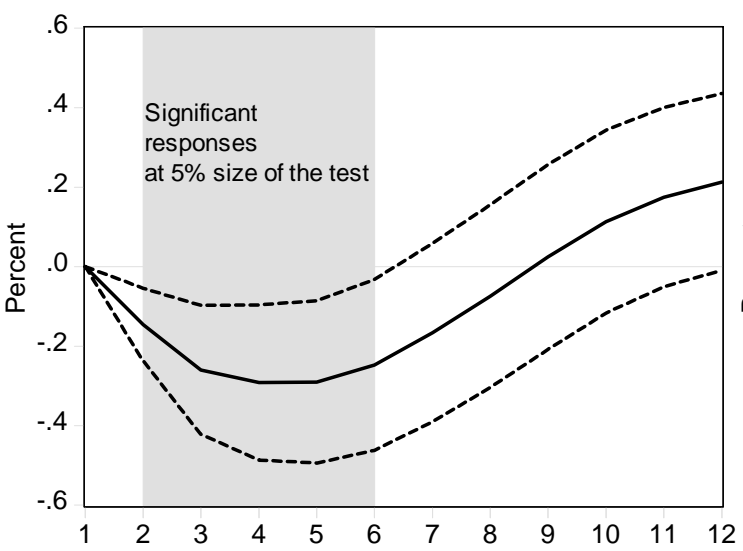

c. Money growth

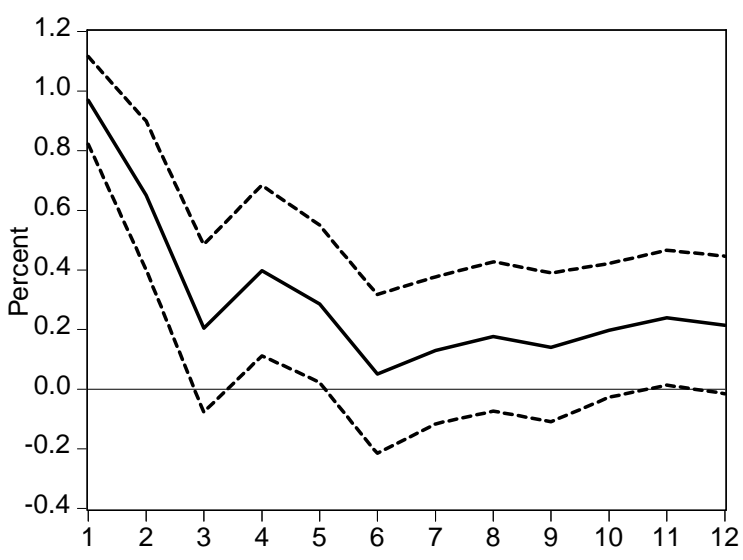

Note: the dotted lines give the $95 \%$ confidence interval. b. Inflation

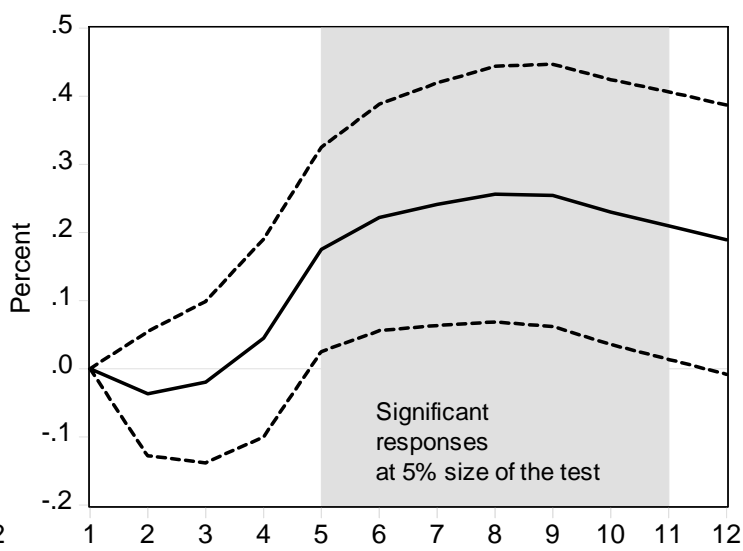

Finally, we compute the long-run inflation and unemployment effects of a permanent shift in money growth as the sum of their significant responses to the one-off shock in money growth. We find that the long-run slope of the Phillips curve is -2.57 with an "upper" bound equal to -14.6 and a "lower" bound equal to -0.33 , where the upper and

\footnotetext{
${ }^{38}$ According to Sims (1992), the price puzzle arises from biased impulse responses due to omitted variables.

${ }^{39}$ These results are available upon request.
} 
lower bounds have been evaluated using the boundary values of the $95 \%$ confidence intervals of the inflation and unemployment responses.

\section{Conclusions}

In this paper we examined the implications of frictional growth for the inflation-unemployment tradeoff. In the context of a simple theoretical macro model, we examined how a long-run tradeoff can arise from the interaction between money growth and various nominal frictions.

Along these lines, we constructed an empirical macro-labour model for the US spanning the 1960-2005 period, and consisting of wage and price setting equations on its nominal side, and labour demand and supply, productivity, and financial wealth equations on its real side. Our approach jointly determines the driving forces of inflation and unemployment. The estimated model is used to evaluate the inflation-unemployment tradeoff, and appraise the performance of the US economy during the roaring nineties.

Our findings can be summarised as follows. First, a permanent shift in money growth generates hump-shaped IRFs, in line with stylised facts, and a downward-sloping longrun Phillips curve with a slope of -3.5. Application of the GMM and SVAR econometric techniques, to a semi-annual dataset covering the same period, indicates the robustness of such a long-run inflation-unemployment tradeoff.

Second, we carried out "accounting" simulations of our empirical CRT model over the 1993-2000 period to measure the contributions of the various factors to the evolution of inflation and unemployment during these years. We found that, by 2000, (i) the increase in productivity growth was responsible for a 1 percentage point (pp) fall in inflation and a $0.4 \mathrm{pp}$ fall in unemployment, (ii) the increase in money growth generated a 2.7 pp increase in inflation, and a $1.8 \mathrm{pp}$ decrease in unemployment, (iii) the virtual elimination of the budget deficit led to a $1.3 \mathrm{pp}$ fall in inflation and a $0.4 \mathrm{pp}$ fall in unemployment, and (iv) the deterioration of the trade deficit decreased inflation by $2.5 \mathrm{pp}$, and unemployment by $0.3 \mathrm{pp}$. It is important to note that the impacts of productivity growth, budget and trade deficits on unemployment were only manifested after 1997.

In a nutshell, the increase in money growth put upward pressure on inflation and substantially lowered unemployment. On the other hand, the rise in productivity growth, the budget deficit reduction, and the increase in the trade deficit put downward pressure on inflation and had a modest impact on the unemployment rate. The resulting low unemployment and subdued inflation rates symbolise the "roaring nineties". Although the New Economy played its role, it is not the sole contributor to the fabulous performance of the US economy during the nineties. Our analysis can effectively explain what Stiglitz (2003, p. 44) describes as 'a lucky mistake - a right decision made for the wrong reasons', and Blinder and Yellen (2002, p. 23) call 'an unusual coincidence of timing and policy...this is 
not a formula that can be repeated at will.'

\section{References}

[1] Ball, L. and R. Moffit (2002): "Productivity growth and the Phillips curve" in A. Krueger and R. Solow (eds.), The Roaring Nineties: Can Full Employment Be Sustained?, Russell Sage Foundation, New York.

[2] Bårdsen, G., E. Jansen, and R. Nymoen (2004): Econometric Evaluation of the New Keynesian Phillips Curve, Oxford Bulletin of Economics and Statistics, 66, pp. 671-686.

[3] Bean, C. (2007): "Globalisation and inflation", World Economics, 8 (1).

[4] Bernanke, B.S. and A.S. Blinder (1992): "The Federal Funds Rate and the Channels of Monetary Transmission", The American Economic Review, 82 (4), pp. 901-921.

[5] Blinder, A.S. and J.L. Yellen (2002): "The Fabulous Decade: Macroeconomic Lessons from the 1990s", The Century Foundation, New York.

[6] Chari, V. V., Kehoe, P., and E. McGrattan (2000): "Sticky Price Models of the Business Cycle: Can the Contract Multiplier Solve the Persistence Problem?", Econometrica, 68 (5), pp. 1151-1179.

[7] Christiano, L. J., Eichenbaum, M., and C.L. Evans (1999): "Monetary Policy Shocks: What Have We Learned and to What End?", in Handbook of Macroeconomics, Vol. 1A, M. Woodford and J. Taylor (eds.), Elsevier Science, North-Holland, Amsterdam, New York and Oxford.

[8] Christiano, L. J., Eichenbaum, M., and C.L. Evans (2005): "Nominal Rigidities and the Dynamic Effects of a Shock to Monetary Policy", Journal of Political Economy, 113 (1), pp. $1-45$.

[9] Cooley, T. F., and G. D. Hansen (1989): "Sticky Price Models of the Business Cycle: Can the Contract Multiplier Solve the Persistence Problem?", American Economic Review, 79 (4), pp. 733-748.

[10] Cooley, T. F., and V. Quadrini (1999): "A Neoclassical Model of the Phillips Curve Relation", Journal of Monetary Economics, 44, pp. 165-193.

[11] Dedola, L., and F. Lippi (2005): "The Monetary Transmission Mechanism: Evidence from the Industries of Five OECD Countries", European Economic Review, 49 (6), pp. 1543-1569.

[12] Friedman, B. J. (2006): "The Greenspan era: Discretion rather than rules", The American Economic Review, 96 (2), pp. 174-177.

[13] Gordon, R.J. (1998): "Foundations of the Goldilocks economy: supply shocks and the TimeVarying NAIRU", Brooking Papers on Economic Activity, 2, pp. 297-346.

[14] Hamermesh, D.S. (2006): "Overtime Laws and the Margins of Work Timing," in: Askenazy, P., D. Carton, F. de Coninck and M. Gollac (eds.), Organisation et Intensité du Travail, Octares Editions, Paris.

[15] Karanassou, M. and D.J. Snower (2004): "Unemployment Invariance," The German Economic Review, 5 (3), pp. 297-317.

[16] Karanassou, M. and D.J. Snower (2007): "Inflation Persistence and the Phillips Curve Revisited", IZA Discussion Paper, 2600, Bonn. 
[17] Karanassou, M., H. Sala and P.F. Salvador (2006): "The (IR)relevance of the NRU for policy making: The case of Denmark," IZA Discussion Paper, 2397, Bonn.

[18] Karanassou, M., H. Sala and P.F. Salvador (2007): "Capital Accumulation and Unemployment: New Insights on the Nordic experience," mimeo.

[19] Karanassou, M., H. Sala and D.J. Snower (2005): "A Reappraisal of the InflationUnemployment Trade-off", European Journal of Political Economy, 21 (1), pp. 1-32.

[20] Karanassou, M., H. Sala and D.J. Snower (2006): "Phillips Curves and Unemployment Dynamics: A Critique and a Holistic Perspective," IZA Discussion Paper, 2265, Bonn.

[21] Karanassou, M., H. Sala and D.J. Snower (2007): "Long-run inflation-unemployment dynamics: The Spanish Phillips curve and economic policy", Journal of Policy Modeling, 29, forthcoming.

[22] Leeper, E. M., Sims A., and T. Zha (1996): "What Does Monetary Policy Do?", Brookings Papers on Economic Activity, 1996, 2, pp. 1-78.

[23] Lin, C.C. (2003): "A backward-bending labor supply curve without an income effect", Oxford Economic Papers, 55, pp. 336-343.

[24] Madsen, J.B. and E. Philip Davis (2006): "Equity prices, productivity growth and "the new economy'," The Economic Journal, 116, pp. 791-811.

[25] Mankiw, N.G. (2001): "The inexorable and mysterious tradeoff between inflation and unemployment," The Economic Journal, 111, C45-C61.

[26] Mankiw, N. G., and R. Reis (2002): "Sticky Information versus Sticky Prices: A Proposal to Replace the New Keynesian Phillips Curve", Quarterly Journal of Economics, 117 (4), 1295-1328.

[27] Merkl, C. and D.J. Snower (2006): "Monetary Persistence, Imperfect Competition and Staggering Complementarities", CEPR Discussion Paper, 5658, London.

[28] Mishkin, F. (2006): "Monetary policy strategy: How did we get here", NBER Discussion Paper, 12515.

[29] Orphanides, A. and R. Solow (1990): "Money, inflation, and growth", in Friedman, B.M. and F.H. Hahn (eds.), Handbook of Monetary Economics, vol. 1, Amsterdam, North Holland.

[30] Pesaran, M. H. (1997), "The Role of Economic Theory in Modelling the Long Run", The Economic Journal, 107(440), January, pp. C178-C191.

[31] Pesaran, M.H. and Shin, Y. (1999). "An Autoregressive Distributed-Lag Modelling Approach to Cointegration Analysis" in Strom, S. (ed.), Econometrics and Economic Theory in the Twentieth Century: The Ragnar Frisch Centennial Symposium: pp. 371-413. Cambridge University Press.

[32] Pesaran, M.H., Shin, Y. and Smith, R.J. (2001): "Bounds testing approaches to the analysis of level relationships", Journal of Applied Econometrics, 16, pp. 289-326.

[33] Phelps, E. S. (1999): "Behind this structural boom: the role of asset valuations", American Economic Review, Papers and Proceedings, 89 (2), pp. 63-68.

[34] Phelps, E. (2006): "Global change needs flexibility, not a fixed rule", Financial Times, May 25, 2006. 
[35] Pivetta, F., and R. Reis (2007): "The Persistence of Inflation in the United States", Journal of Economic Dynamics and Control, 31, pp. 1326-1358.

[36] Raddatz, C., and R. Rigobon (2003): "Monetary Policy and Sectoral Shocks: Did the Fed React Properly to the High-Tech Crisis?" NBER Working Paper 9835.

[37] Ribba, A. (2007): "Permanent disinflationary effects on unemployment in a small open economy: Italy 1979-1995", Economic Modelling, 24, pp. 66-81.

[38] Rudebusch, G.D. (1998): "Do Measures of Monetary Policy in a Var Make Sense?”, International Economic Review, 39 (4), pp. 907-931.

[39] Sidrauski, M. (1967): "Rational Choice and Patterns of Growth in a Monetary Economy", American Economic Review, 57, pp. 534-544.

[40] Sims, C. A. (1992): "Interpreting the Macroeconomic Time Series Facts: The Effects of Monetary Policy", European Economic Review, 36 (5), pp. 975-1011.

[41] Staiger, D. and J. Stock (1997): "Instrumental variables regression with weak instruments", Econometrica, 65 (3), pp. 577-586.

[42] Staiger, D., J. Stock and M. Watson (2002): "Prices, wages and the U.S. NAIRU in the 1990s", in A. Krueger and R. Solow (eds.), The Roaring Nineties: Can Full Employment Be Sustained?, Russell Sage Foundation, New York.

[43] Stiglitz, J.E. (2003): The Roaring Nineties, W.W. Norton \& Company, New York.

[44] Stock, J. and M. Watson (2001): "Vector Autoregressions", Journal of Economic Perspectives, 15 (4), pp. 101-115.

[45] Taylor, J.B. (1993): "Discretion Versus Policy Rules in Practice," Carnegie-Rochester Conference Series on Public Policy, 39, pp. 195-214.

[46] Temple, J. (2002): "Openness, inflation and the Phillips curve: A puzzle", Journal of Money, Credit and Banking, 34 (2), pp. 450-468. 